NIPER-578

Distribution Category UC-122

Feasibility Study of Heavy Oil Recovery in the Permian Basin

(Texas and New Mexico)

Topical Report

By

D.K. Olsen

W.I. Johnson

May 1993

Work Performed Under Cooperative Agreement No. DE.FC22-83FE60149

Prepared for

U.S. Department of Energy

Assistant Secretary for Fossil Energy

Tom Reid, Project Manager

Bartlesville Project Office

P. O. Box 1398

Bartlesville, OK 74005

Prepared by

IIT Research Institute

National Institute for Petroleum and Energy Research

P.O. Box 2128

Bartlesville, OK 74005 


\section{TABLE OF CONTENTS}

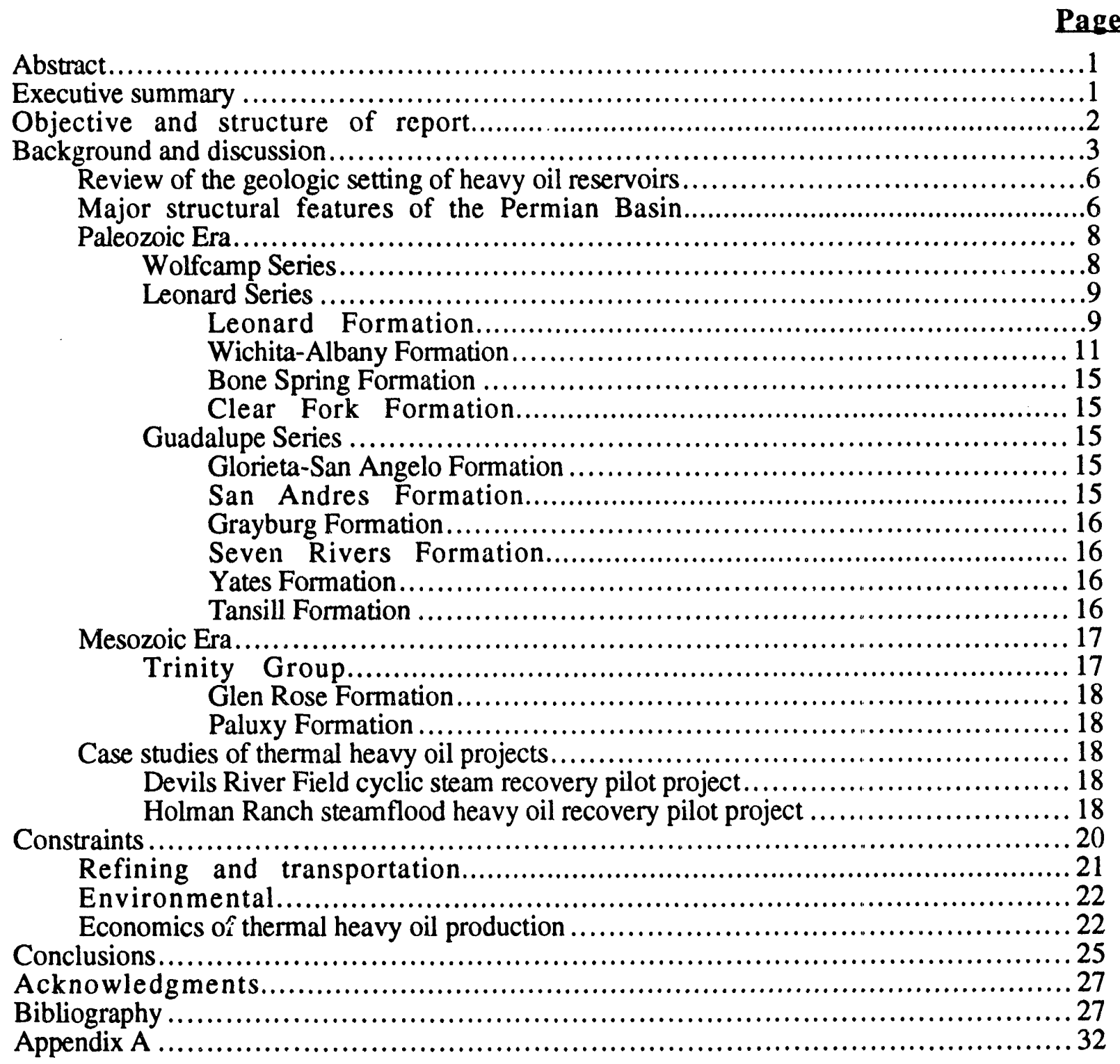

\section{TABLES}

1. Devil's River Field cyclic steam recovery project......................................... 20

2. Holman Ranch field steamflood recovery pilot project..................................... 21

3. Thermal EOR operating costs .................................................. 23

4. Yearly thermal steam operating cost ranges within each field/well in California..........23

5. Comparison of economic factors affecting oil production in the Permian Basin........ 24

\section{APPENDIX A TABLES}

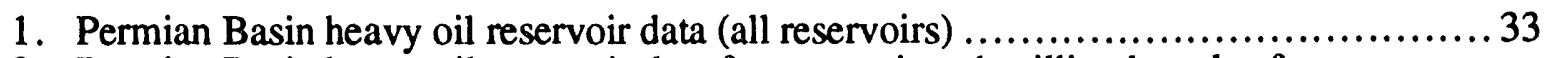

2. Permian Basin heavy oil reservoir data for reservoirs $>1$ million barrels of original-oil-in-place. 


\section{ILLUSTRATIONS}

Page

1. Index map of principal structural elements in the Permian Basin ........................4

2. Location map showing Yates and Toborg fields, Pecos County, Texas.................. 4

3. Stratigraphic column for Toborg and Yates fields ...................................

4. Correlation chart, Permian Basin of West Texas and Southeast New Mexico .............7

5. Paleographic map of West Texas \& Sovineast New Mexico during Late Ellenburger .....8

6. Dominant lithofacies of Wolfcampian 'Series..........................................9

7. Thickness of Wolfcampian Series............................................. 10

8. Dominant lithofacies of Leonardian Series .............................................. 10

9. Thickness of Leonardian Series............................................................

10. Lithofacies map of the Abo-Wichita Albany Reef Trend Permian, Lower Leonard Series Permian Basin of West Texas and Southeast New Mexico............................ 12

11. Dominant lithofacies of Guadalupe Series............................................ 13

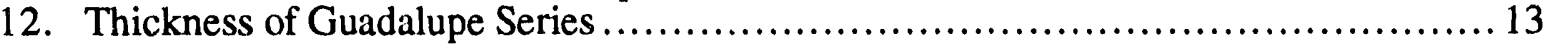

13. Dominant lithofacies of Upper Guadalupe Series............................................. 14

14. Generalized Permian shelf-to-basin cross section of the Northwestern Delaware

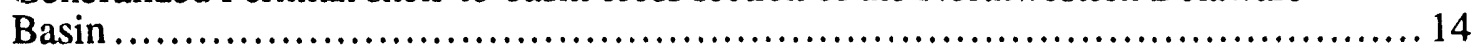

15. Generalized deposition of red beds in relation to sea level................................. 17

16. Composite stratigraphic sections for Devils River Uplift-Southern Val Verde, Basin, Texas ......................................................................... 19

17. Pipelines carrying heavy oil into and out of the Permian basin to the Midwest and

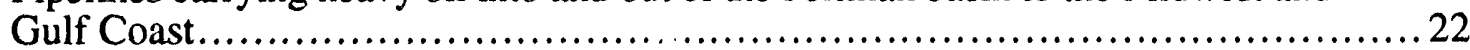

18. Comparison of average oil price of benchmark crude oils ............................26

19. Ratio of oil prices for benchmark heav'y and light crude oils.........................26 


\title{
FEASIBILITY STUDY OF HEAVY OIL RECOVERY IN THE PERMIAN BASIN (TEXAS AND NEW MEXICO)
}

By D. K. Olsen and W. I. Johnson

\begin{abstract}
This report is one of a series of publications assessing the feasibility of increasing domestic heavy oil production. Each report covers select areas of the United States. The Permian Basin of West Texas and Southeastern New Mexico is made up of the Midland, Delaware, Val Verde, and Kerr Basins; the Northwestern, Eastern, and Southern shelves; the Central Basin Platform, and the Sheffield Channel. The present day Permian Basin was one sedimentary basin until uplift and subsidence occurred during Pennsylvanian and early Permian Age to create the configuration of the basins, shelves, and platform of today. The basin has been a major light oil producing area served by an extensive pipeline network connected to refineries designed to process light sweet and limited sour crude oil. Limited resources of heavy oil ( $10^{\circ}$ to $20^{\circ}$ API gravity) occurs in both carbonate and sandstone reservoirs of Permian and Cretaceous Age. The largest cumulative heavy oil production comes from fluvial sandstones of the Cretaceous Trinity Group. Permian heavy oil is principally paraffinic and thus commands a higher price than asphaltic California heavy oil. Heavy oil in deeper reservoirs has solution gas and low viscosity and thus can be produced by primary and by waterflooding. Because of the nature of the resource, the Permian Basin should not be considered a major heavy oil producing area.
\end{abstract}

\section{EXECUTIVE SUMMARY}

This report is one of a series of publications assessing the feasibility of increasing domestic heavy oil production. Each report covers select areas of the United States. This report covers the Permian Basin of West Texas and Southeastern New Mexico which produces limited heavy oil ( $10^{\circ}$ to $20^{\circ}$ API gravity) from consolidated reservoir rocks of Permian and Cretaceous Age. There are a few sandstone reservoirs within the Permian Basin, but carbonate rocks are the dominant type of reservoir rock. Toborg Field located on the extreme southern end of the Central Basin Platform of the Permian Basin is the largest heavy oil field in the basin and has been reported to produce about $41,000,000$ barrels of oil, however, only part of it is actually heavy oil. With cumulative heavy oil production of only 72,000,000 barrels, of an estimated 160 to 300 million barrels originally in place (OIP), the Permian Basin is a minor heavy oil producing area as compared to California with about 60 billion barrels OOIP. Cumulative oil production in the Permian Basin (light and heavy) is $>24$ billion barrels, thus heavy oil is $<0.3 \%$ of total oil produced. The Cretaceous Trinity Group fluvial sandstone has produced $56 \%$ of the heavy oil produced in the Permian Basin. Because of the mature state of exploration and production in this basin, the 
discovery of new, significant heavy oil resources is unlikely. Significant oil production by thermal enhanced oil recovery (TEOR) is unlikely because most of the reservoirs are carbonates and thermal recovery from carbonates has not proven to be commercial. Thermal recovery from consolidated sandstones has not proven to be highly economic. Toborg field, a Trinity Group sandstone reservoir, has been waterflooded on 2.5 -acre spacing to recover $57 \%$ of the estimated OOIP. Much of the oil in Toborg is believed to have migrated upward into the shallower, lowpressure, sandstones during early development of giant Yates Field. Toborg's sandstones were not protected (isolated by cementing the entire production string) from the high-pressure Yates. Much of Toborg's oil is believed to originate as light oil, $>20^{\circ}$ API. There are conflicting reports on the API gravity of this oil and the range of gravity across the field because only about $500 \pm$ acres may actually be a productive heavy oil reservoir.

The Permian Basin has been a major light oil producer having an extensive light oil collection and pipeline network going to predominantly light oil refineries. Heavy oil and Alaskan North Slope oil is transported from California as a blend by the All-American pipeline through the Permian Basin to refineries on the Gulf Coast and the Midiwest. The basin has an extensive infrastructure supporting extensive primary production, aging and rapidly declining waterfloods, and a growing production from $\mathrm{CO}_{2}$ enhanced oil recovery projects, The environmental problems and changes from implementation of limited TEOR processes are low because of the anticipated low cumulative heavy oil production and the nature of the resource. The oil in the Permian Basin is principally paraffinic unlike the asphaltic California heavy crudes. Paraffinic crudes command a higher price than asphaltic oils of the same gravity. Within the Permian Basin, there are deep $(>5,000 \mathrm{ft})$ hot reserv jirs with significant solution gas in the heavy oil that produce on primary or are waterfloodable. The Permian Basin is anticipated to be a minor heavy oil producer due to the consolidated nature of the reservoir rock, the internal architecture of the reservoirs, the reservoir depth and the nature of the reservoir rock where most reservoirs are carbonates. Horizontal wells and infill wells may contribute to increased recovery' of heavy oil resources in the Permian Basin due to better sweep efficiency in waterfloods. The results of this study show that because of the limited potential for major heavy oil development, this basin bears no further investigation of its heavy oil resources. However, significant improvement in the reservoir data could be achieved by obtaining information directly from field operations.

\section{OBJECTIVE AND STRUCTURE OF REPORT}

The objectives of this feasibility study are (1) to investigate from secondary data the known heavy oil resources in the Permian Basin of West Texas and New Mexico (Fig. 1, Ward et al., 1986); (2) to screen this resource for potential thermal or other enhanced oil recovery applications; and (3) to evaluate various economic facets that may impact the development of this resource. If the study determines that expansion of production of heavy oil is economically possible by recent 
advances in technology, recommendations will be made to facilitate the production of this additional resource.

As one of a series of reports on the feasibility of heavy oil recovery in the U.S., this study analyzed the geologic settings of the Permian Basin heavy oil reservoirs and the limited TEOR projects that have been attempted. This limited review of secondary publicly available data attempts to list the constraints to heavy oil production, define the transportation network, and refining capabilities, review environmental restrictions and economic considerations that impact heavy oil development. NIPER's analysis of the secondary field data is included at the end of this report as Table 1. The approach used in this study reviewed the public literature analyzing each geologic unit in each basin for the presence of heavy oil. The analysis started with the oldest sedimentary rocks. Analysis was also conducted on previously published studies (Crysdale and Schenk, 1990) and used the U.S. DOE crude oil database as a source of information on crude oil and their compositions.

Heavy oil as used in this study is defined as having gas-free viscosity of $>100$ and $<10,000$ MPas (centipoise, cP) inclusive at original reservoir temperature or a density of $943 \mathrm{~kg} / \mathrm{m}^{3}\left(20^{\circ}\right.$ API gravity) to $1,000 \mathrm{~kg} / \mathrm{m}^{3}\left(10^{\circ} \mathrm{API}\right.$ gravity) inclusive at $15.6^{\circ} \mathrm{C}\left(60^{\circ} \mathrm{F}\right)$ (Group, 1981). This report uses both the geologic terms "system" a chronostatigraphic (rock) term and "period" a geochronometric (geologic time) as a subdivision of the geologic time scale. Average reservoir data is listed in the Appendix and is sparse because the resource does not justify the effort to judiciously pursue the average reservoir data for heavy oil in carbonate reservoirs.

\section{BACKGROUND AND DISCUSSION}

The Permian Basin is located in West Texas and Southeastern New Mexico. In Texas and New Mexico, the Midland Basin, Delaware Basin, Eastern Shelf of the Midland Basin, Southern Shelf of the Permian Basin, Northwestern Shelf of the Permian Basin, Central Basin Platform, Kerr Basin, Val Verde Basin, Sheffield Channel, etc. make up the present day Permian Basin (Fig. 1, Ward et al., 1986; and Jones, 1953). Cumulative oil production, light (>20 API gravity) and heavy oil ( $10^{\circ}$ to $20^{\circ}$ API gravity), is $>24$ billion barrels (Hance, Sharp and Nugent, 1989). This value includes only cumulative oil produced in Railroad Commission Districts $7 \mathrm{~B}, 7 \mathrm{C}, 8$, and 8A. It does not include cumulative oil produced from the New Mexico part of the Permian Basin. Only 72 million barrels (see appendix A, this report) of this total $(<0.3 \%)$ is heavy oil. Most of the productive formations within the Permian Basin are consolidated formations principally carbonates (limestone or dolomite) with a few sandstone reservoirs, although the largest heavy oil reservoir is sandstone (Fig. 2, Toborg field). Most of the oil producing formations are Permian and younger. A stratigraphic column across the Permian Basin is shown in (Fig. 3). 


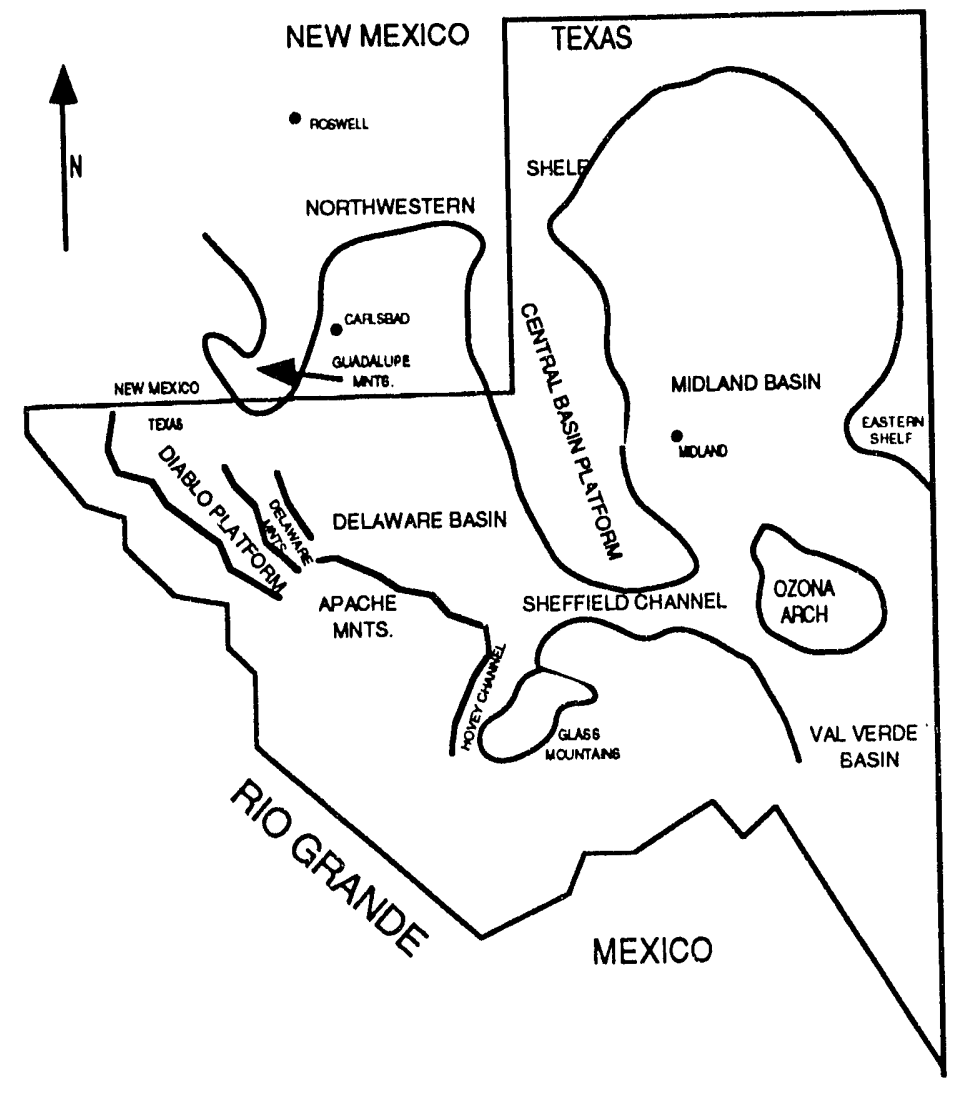

FIGURE 1. - Index map of principal structural elements in the Permian Basin (Ward et al., 1986).

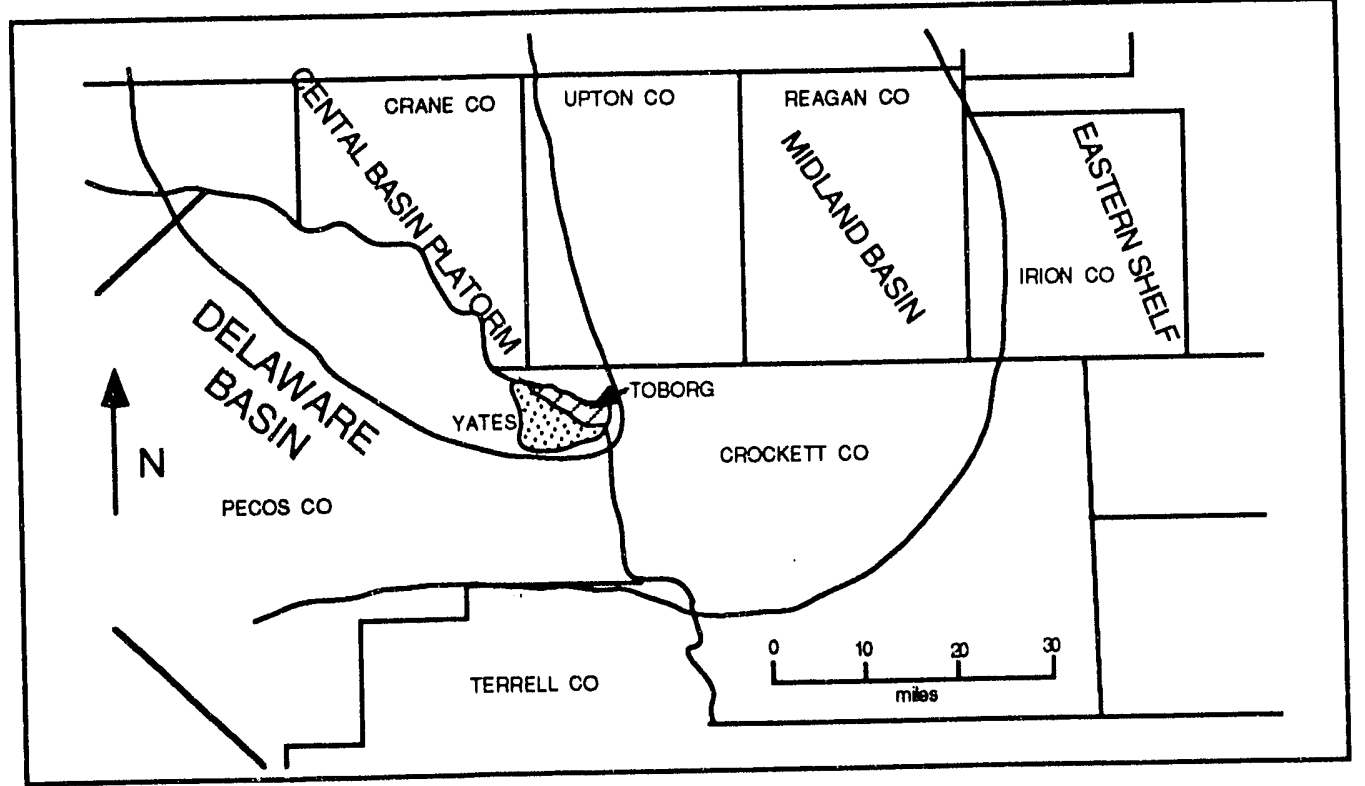

FIGURE 2. - Location map showing Yates and Toborg Fields, Pecos County, Texas (Galloway, Ewing, Barrett, Taylor and Debout, 1983). 


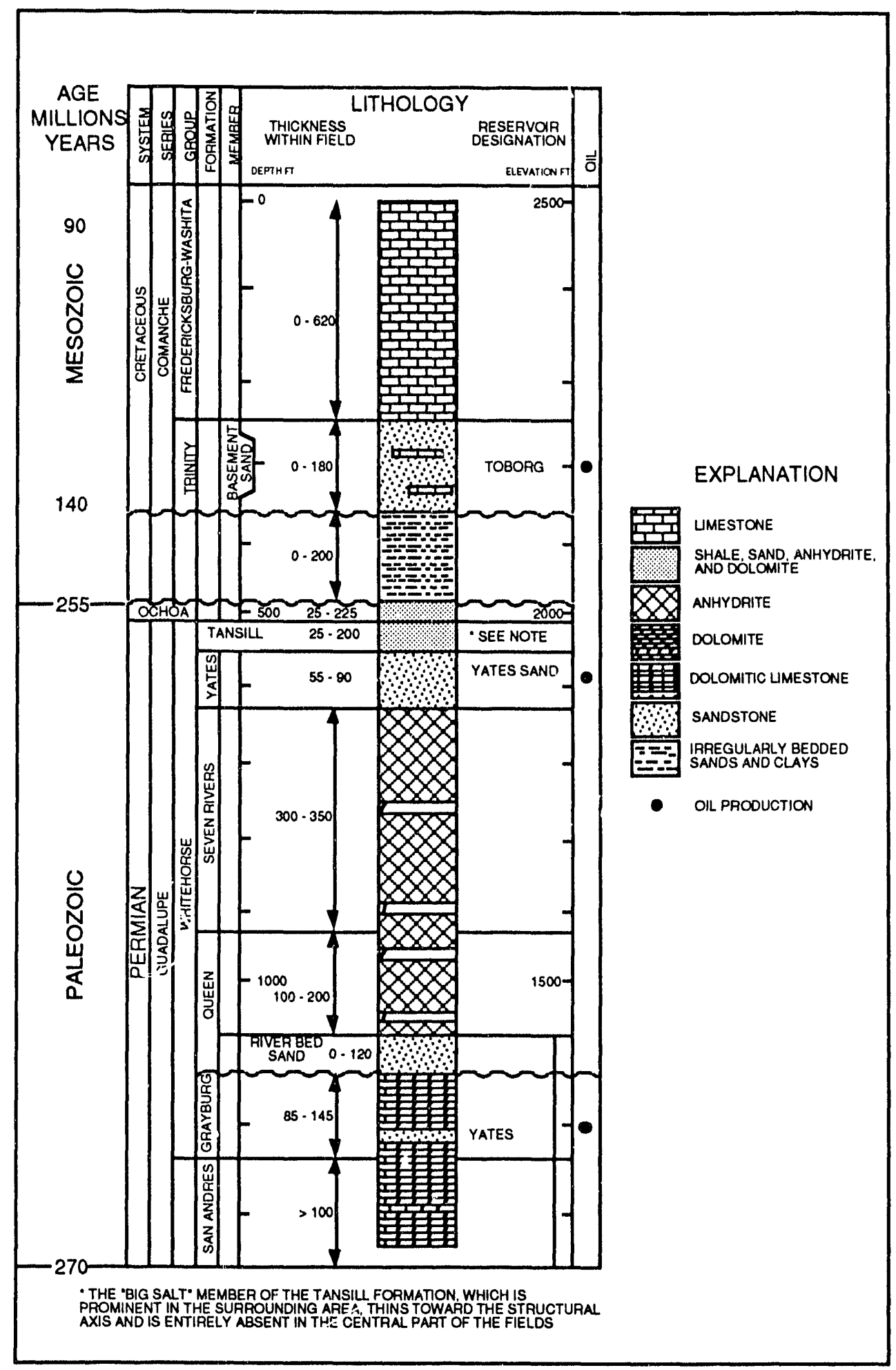

FIGURE 3. - Stratigraphic column for Toborg and Yates fields (Galloway, Ewing, Barrett, Taylor, and Debout, 1983). 
Heavy oil is produced from reservoirs of Paleozoic and Mesozoic Age. These reservoirs are composed of mostly carbonates (limestone and dolomites) and a few sandstone reservoirs. Toborg Field is reported to be the most prolific heavy oil reservoir even though the origin of the oil and the API gravity are suspect (Galloway et al., 1983, p. 100, reports $22^{\circ}$ API gravity; Crysdale and Schenk, 1990 , report $19^{\circ}, 10^{\circ}$ to $30^{\circ}$ API gravity; Gariet, 1992 , states $500 \pm$ acres with $10 \pm$ feet of pay of $20^{\circ}$ API oil; and Hance, Sharp and Nugent, 1989, p. II-262, list Toborg as $19^{\circ}$ API gravity). This fluvial sandstone reservoir is productive from the Cretaceous Trinity Group consolidated sandstone and is the largest heavy oil field in Permian Basin, (Figs. 2 and 3). Toborg Field has produced $57 \%$ of the heavy oil produced in the Permian Basin (Fig. 2). Permian Age formations have produced $44 \%$ of the total heavy oil in this basin. Data from New Mexico is sparse, but the NIPER heavy oil database being developed will fill in blanks of tables in the appendix. An extensive bibliography is included at the end of this report.

\section{Review of the Geology Setting of Heavy Oil Reservoirs}

In the following pages, the geologic setting of the heavy oil resource in the Permian Basin is summarized. The anproach used will be to briefly describe the environment beginning with the rocks of oldest age containing heavy oil and work towards younger aged formations containing heavy oil. Correlation charts (Figs. 3 and 4) are referred to extensively throughout the discussion. Figure 4 shows a correlation chart of formations across West Texas and Southeast New Mexico.

\section{Major Structural Features of the Permian Basin}

At the beginning of the Ordovician Period, the present day configuration of the Permian Basin had not been formed. Prominent structural features at this time were the Pedernal Massif, the Texas Peninsula, Tex-Mex Arch and Alpine Arch. Depocenters in the slowly subsiding basin were in West Texas (Fig. 5). During early Ordovician time, Ellenburger Formation carbonates were deposited in this slowly subsiding, shallow marine shelf that extended from Oklahoma across Texas into New Mexico (Wright, 1979).

During Pennsylvanian and Permian time, the major regional and local tectonic movements occurred to form the present subsurface structural architecture of the Permian Basin of West Texas and Southeastern New Mexico. The major structural features of the Permian Basin are the Delaware Basin of Southeastern New Mexico and West Texas, which is separated from the Midland Basin of West Texas by the Central Basin Platform, the Val Verde and Kerr basins (a southern extension of the Midland Basin), and the Sheffield Channel connecting the Delaware and Midland basins south of the Central Basin Platform. Adjacent to these sedimentary basins of Pennsylvanian and Permian periods are the Northwestern and Southern shelves of the Delaware and Midland basins and the Eastern Shelf of the Midland Basin (Fig. 1) (Wright, 1979; Jones, 1953). 


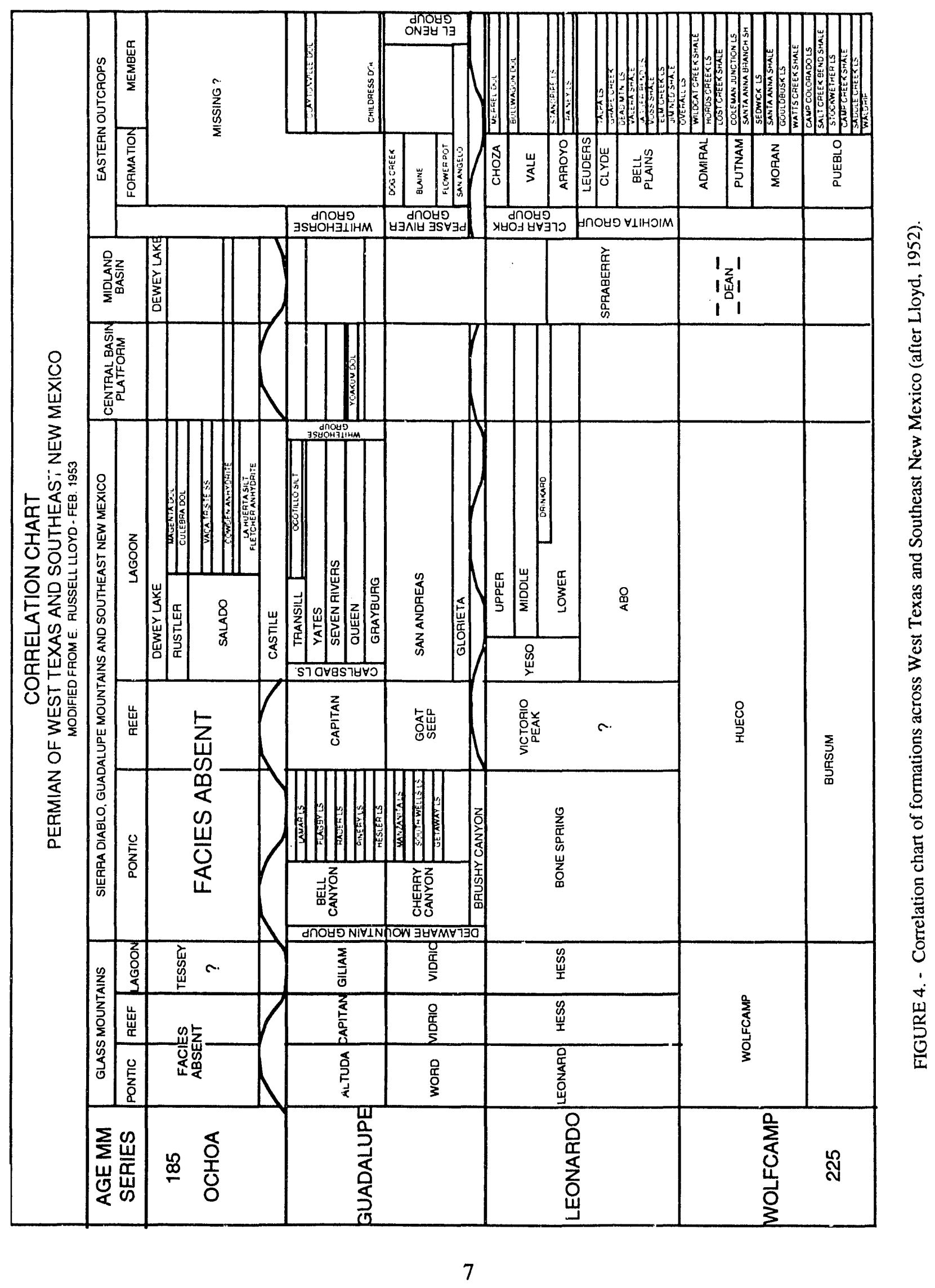




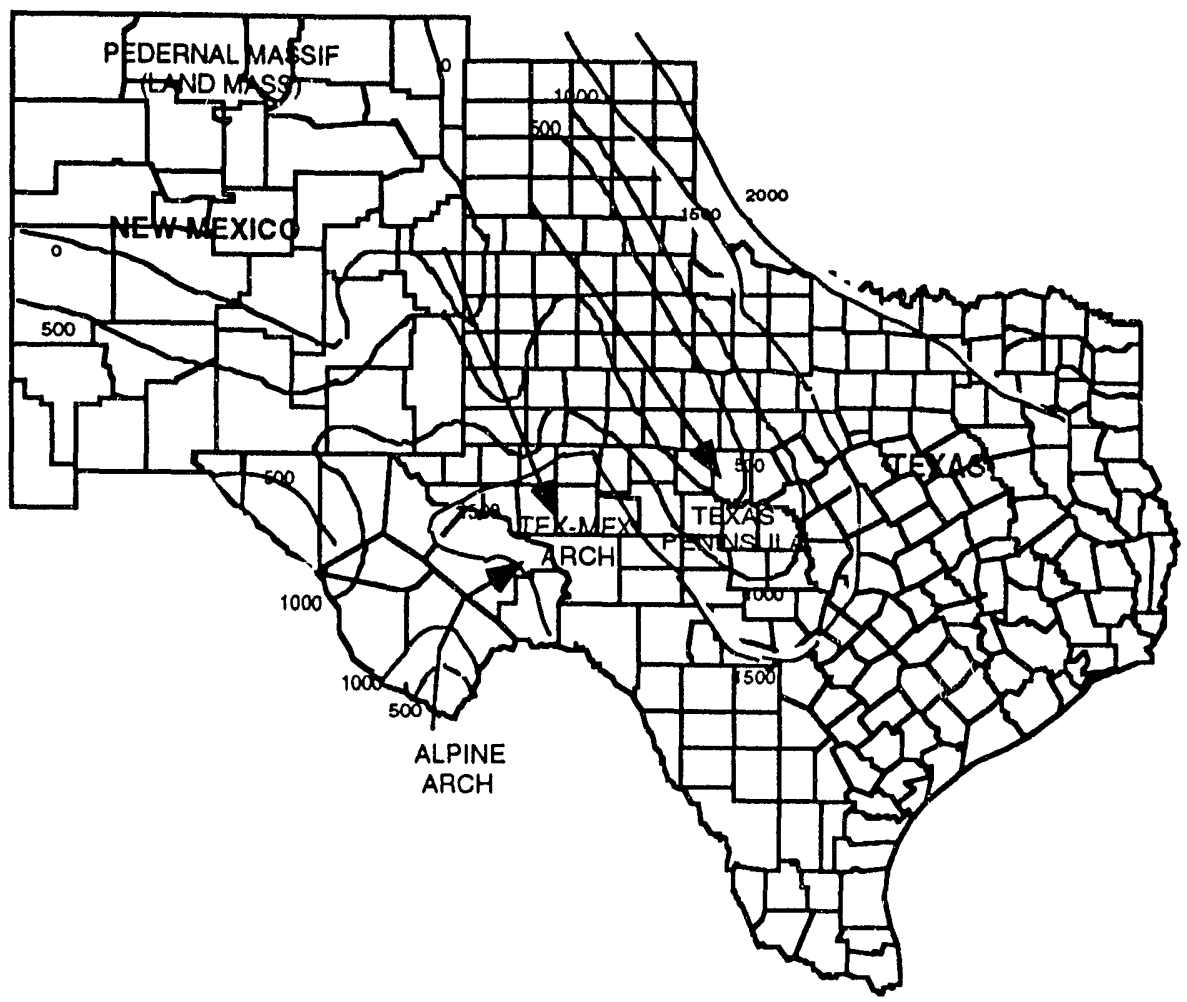

FIGURE 5. - Paleogeographic map of West Texas and Southeast New Mexico during late Ellenburger (Lower Ordovician) time about 415,000,000 years ago, showing isopachs of Ellenburger (Wright, 1979).

\section{Paleozoic Era}

The oldest reservoirs in the Permian Basin containing heavy oil are those of the Permian Wolfcamp series (Fig. 4). Within the Permian System, the Wolfcamp is the oldest, then the Leonard series, Guadalupe series, and the youngest is the Ochoa series. Within each are various groups and formations containing heavy oil. Each reservoir is briefly described and general reservoir properties are listed in the appendix $\mathrm{A}$. and references are cited.

\section{Wolfcamp Series}

There are three heavy oil fields (Blalock Lake East Field in Glasscock County, Texas; Dollarhide East Field in Andrews County, Texas; and Leeper Field in Hockley County, Texas) producing from Wolfcamp Series reservoir rocks in the Permian Basin, all located in the Midland Basin of West Texas (Fig. 1). Reservoir properties are shown in appendix A. Rocks of the Wolfcamp Series are early Permian in age (Fig. 4). Reservoir rock in these fields are dolomite and limestone (Crysdale and Schenk, 1990). The upper Wolfcamp consists of dark, shaley limestone containing fusulinids and dark shale. The lower Wolfcamp is dark shale with little dark argillaceous limestone or finely crystalline dolomite. The Wolfcamp attains a thickness of 2,500 ft 
along the Upton-Reagan county line and thins regionally northward (Figs. 6 and 7). Thinning of the Wolfcamp occurs over structures. The contact between the Wolfcamp and the overlying Leonard is difficult to pick on the basis of either lithology or fauna across the Permian Basin (Jones, 1953).

\section{Leonard Series}

Eight heavy oil fields, described below and whose general reservoir properties are listed in the appendix A, produce from Leonard Series reservoirs in the Leonard, Wichita-Albany, Bone Spring and Clear Fork formations. The Delaware Basin of New Mexico has one of the heavy oil fields in the Bone Spring Formation. Five heavy oil fields are in the Midland Basin of West Texas; one in the Leonard, one in the Wichita Albany, and three in the Clear Fork formation (Figs. 1, 4, 8 and 9). Two heavy oil fields are on the Southern Shelf of the Permian Basin in the Leonard formation.

\section{Leonard Formation}

Two of the Leonard Formation heavy oil fields are located along the Southern Shelf of the Permian Basin (Schuler Field in Pecos County, Texas); and one Leonard Formation heavy oil field is in the Midland Basin (Fluvanna Field in Bordon County, Texas). Reservoir rock in these fields is limestone and dolomite (Crysdale and Schenk, 1990). These carbonate rocks were deposited on a shallow shelf that extended into the Permian Basin (Fig. 8). The Leonard thickens westward
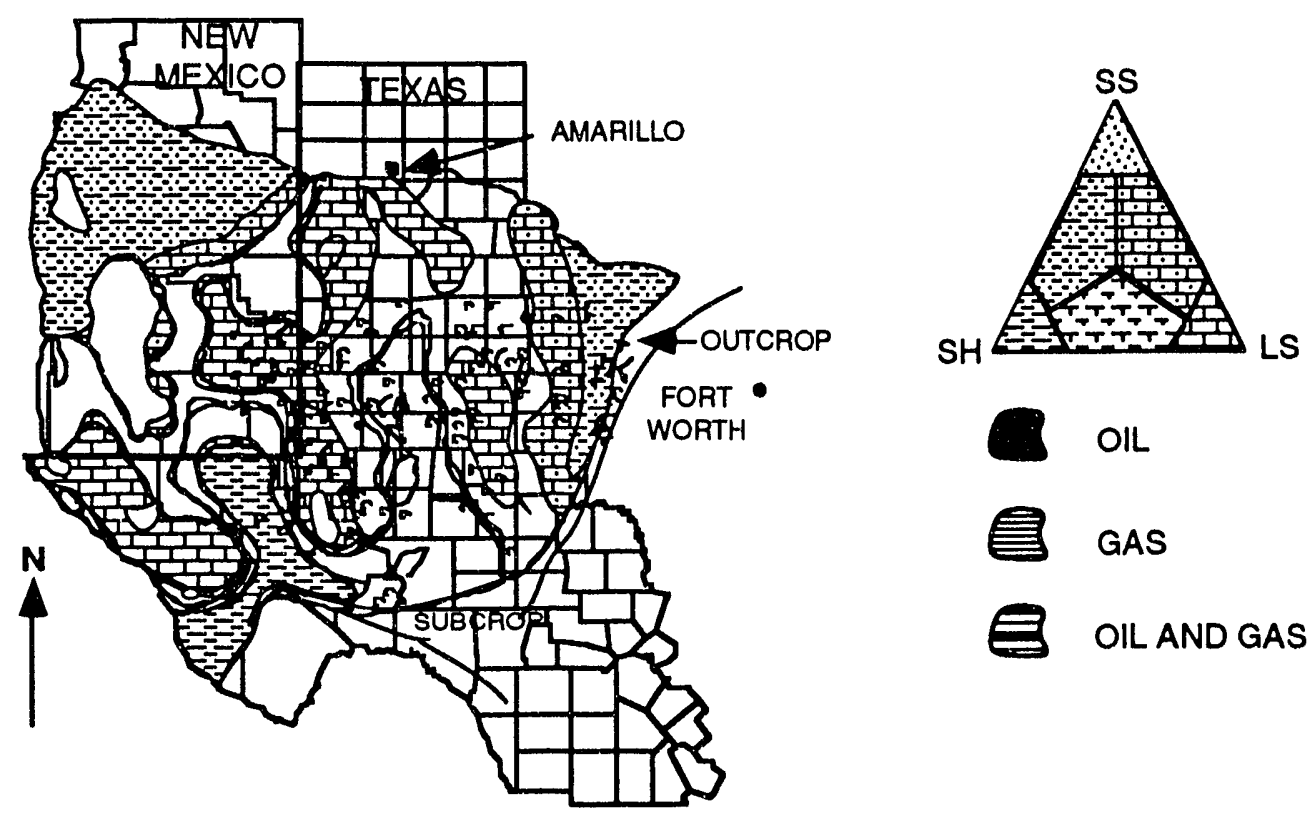

FIGURE 6. - Dominant lithofacies of Wolfcampian Series. Oil and gas fields in reservoirs of the age are shown. Compiled and modified from Galley (1958), Dixon (1967), and Oriel et al (1967). 


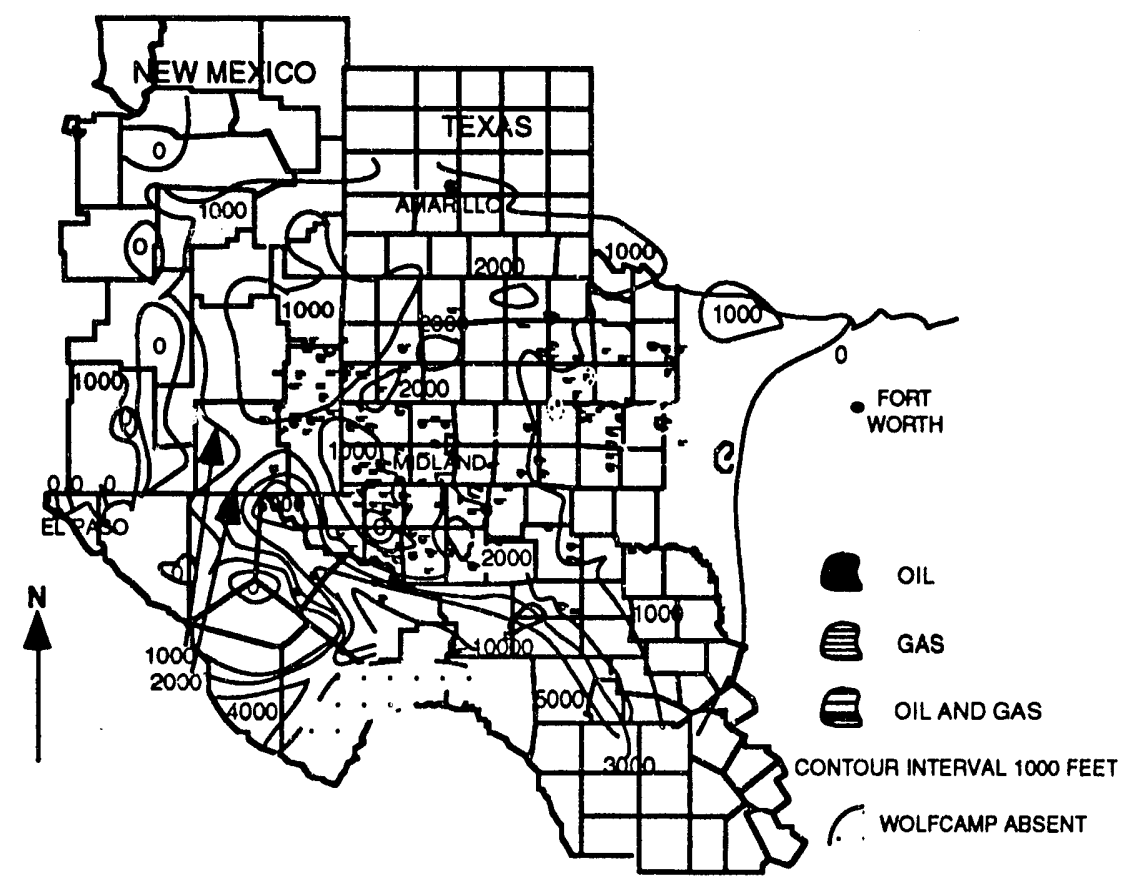

FIGURE 7. - Thickness of Wolfcampian Series. Oil and gas fie'd: $n$ reservoirs of the age are shown. Compiled and modified from Galley (1958), Dixon (1967), and Oriel et al (1967) alterations by Hartman and Woodard.

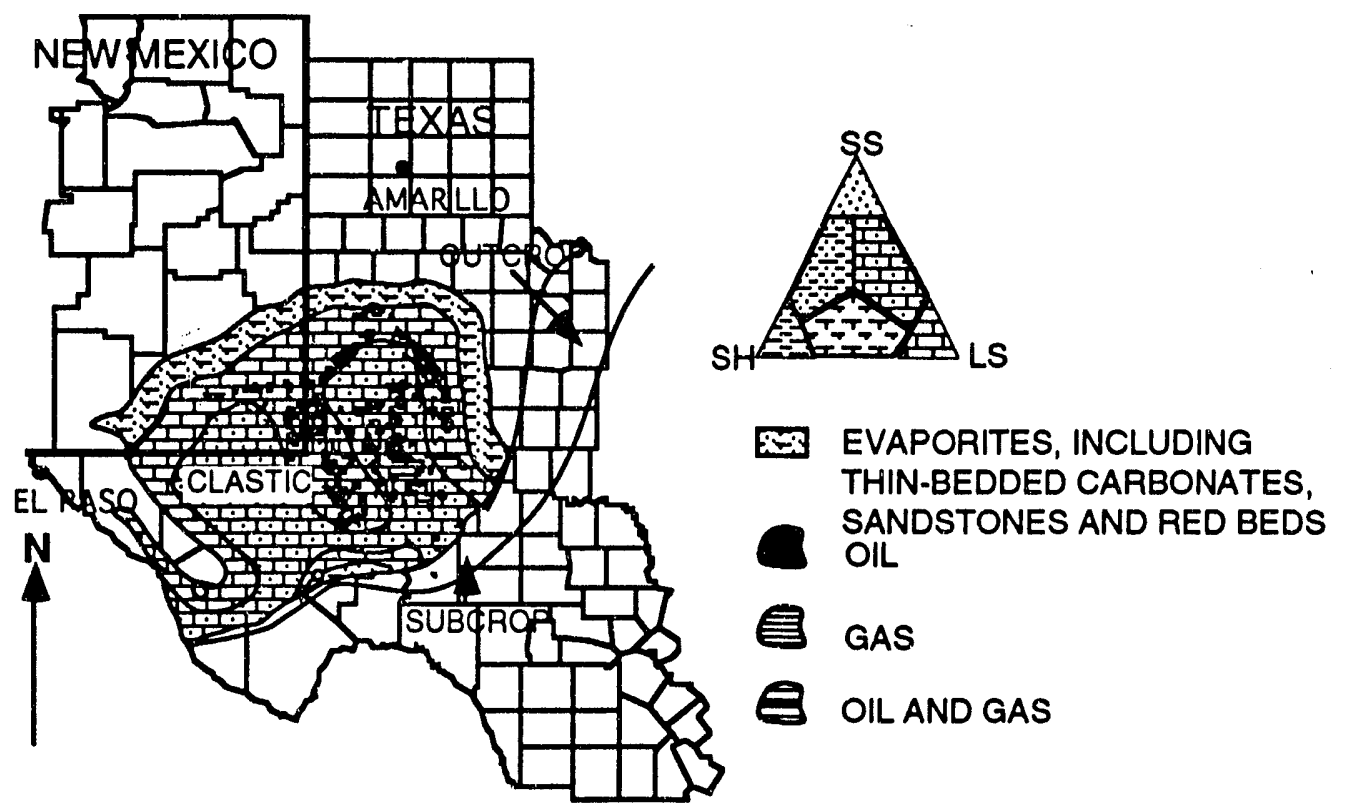

FIGURE 8. - Dominant lithofacies of Leonardian Series. Oil and gas fields in reservoirs of the age are shown. Compiled and modified from Galley (1958), Dixon (1967), and Oriel et al (1967) alterations by Hartman and Woodard. 


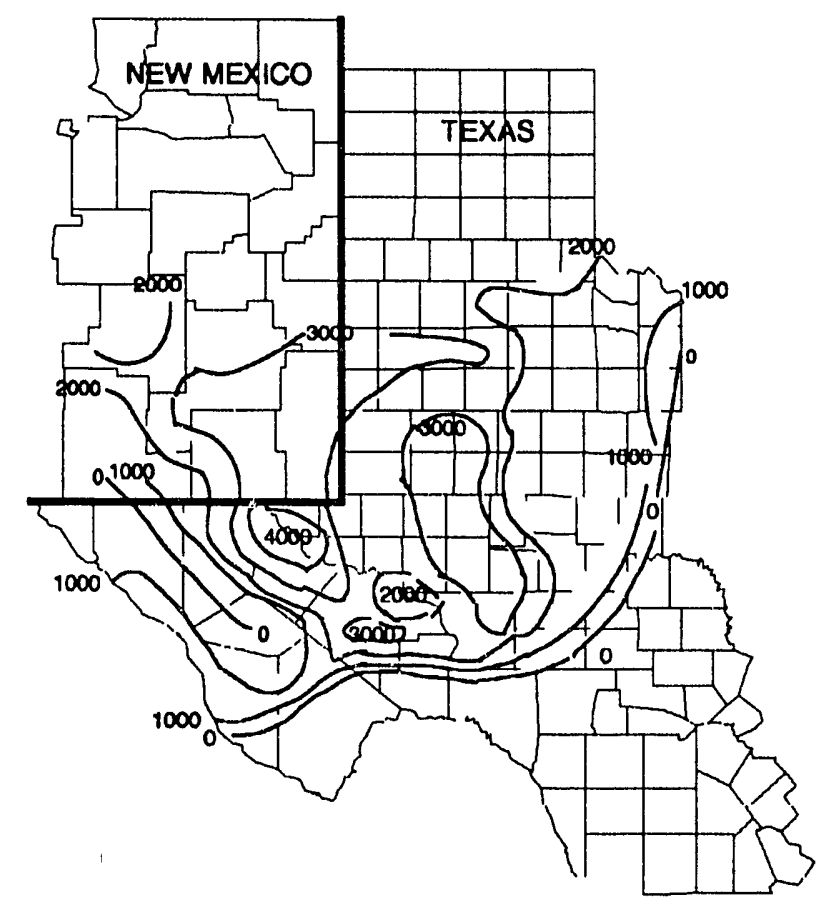

FIGURE 9. - Thickness of Leonardian Series. Oil and gas fields in reservoirs of the age are shown. Compiled and modified from Galley (1958), Dixon (1967), and Oriel et al (1967) alterations by Hartman and Woodard.

from the pinchout on the Eastern Shelf of the Midland Basin to a thickness of 3,000 $\mathrm{ft}$ in the Midland Basin. It also thickens northward from the pinchout on the Southern Shelf of the Permian Basin to a thickness of more than 4,000 ft in the Delaware Basin of West Texas and New Mexico (Fig. 9) (Hartman and Woodard, 1971).

\section{Wichita-Albany Formation}

The Log-Pat Field in Scurry County, Texas produces heavy oil from the Wichita-Albany Formation on the Eastern Shelf of the Midland Basin (Fig. 1). Reservoir rock in this area is limestone and dolomite (Crysdale and Schenk, 1990). Two carbonate facies were deposited along the eastern margin of the Midland Basin, a reef facies and a backreef facies to the east onto the Eastern Shelf (Fig. 8). The reef facies is clean, light-colored, massive dolomite. Locally, it can be limestone associated with dolomite. Thickness of the reef facies averages approximately $800 \mathrm{ft}$ along the eastern margin of the Midland Basin. The backreef facies to the east along the Eastern Shelf which is made up of white to tan to brown, bedded anhydritic dolomite, interbedded with thin beds of gray and green shale and anhydrite with small amounts of chert associated with the dolomite. Dolomite and anhydrite facies suggest that these sediments may be associated with barrier reefs. Locally, there are porous lenses of dolomite developed (Figs. 8 and 10) (Wright, 1979). 


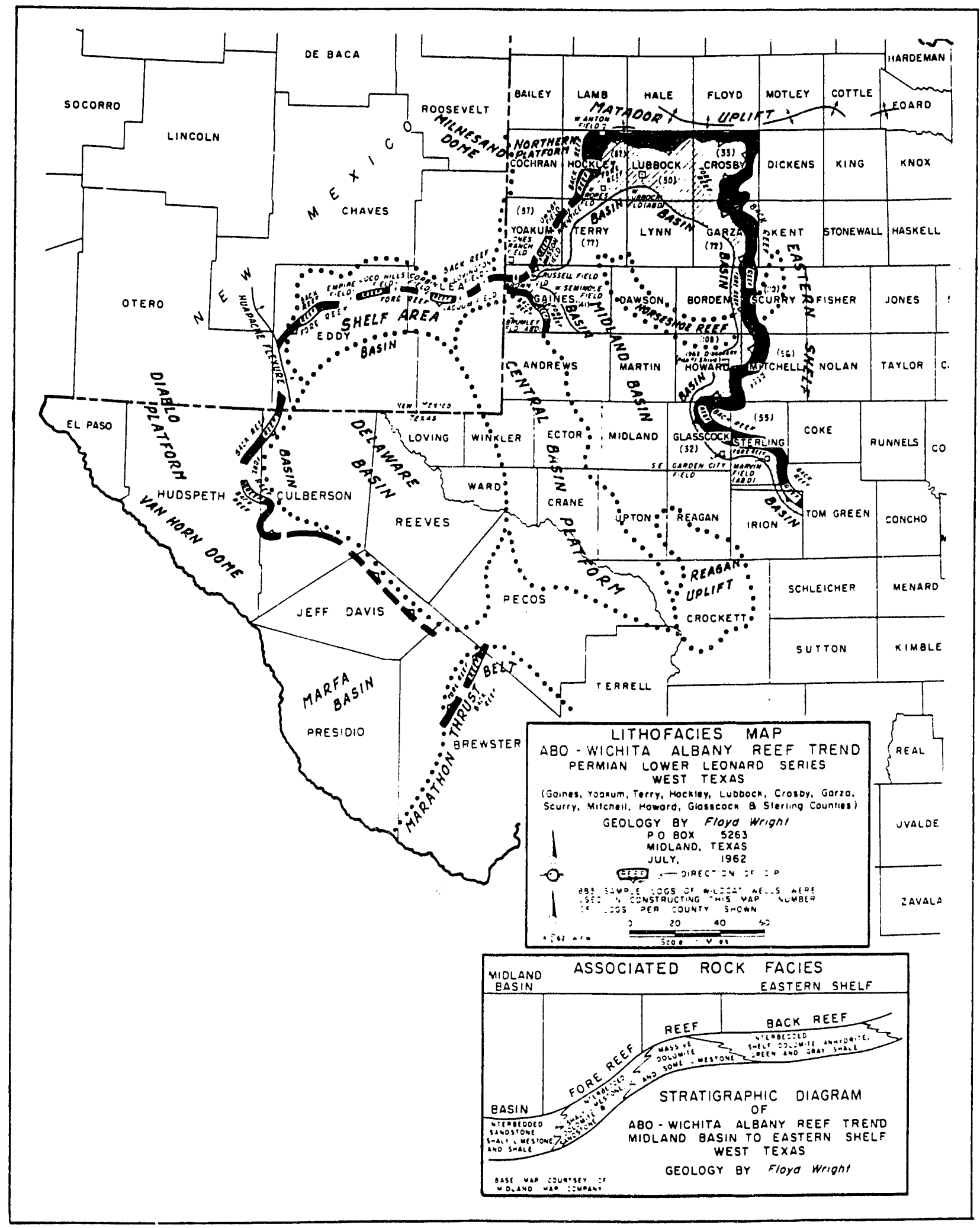

FIGURE 10. - Lithofacies map of the Abo-Wichita Albany Reef Trend Permian, Lower Leonard Series Permian Basin of West Texas and Southeast New Mexico (Wright, 1979). 


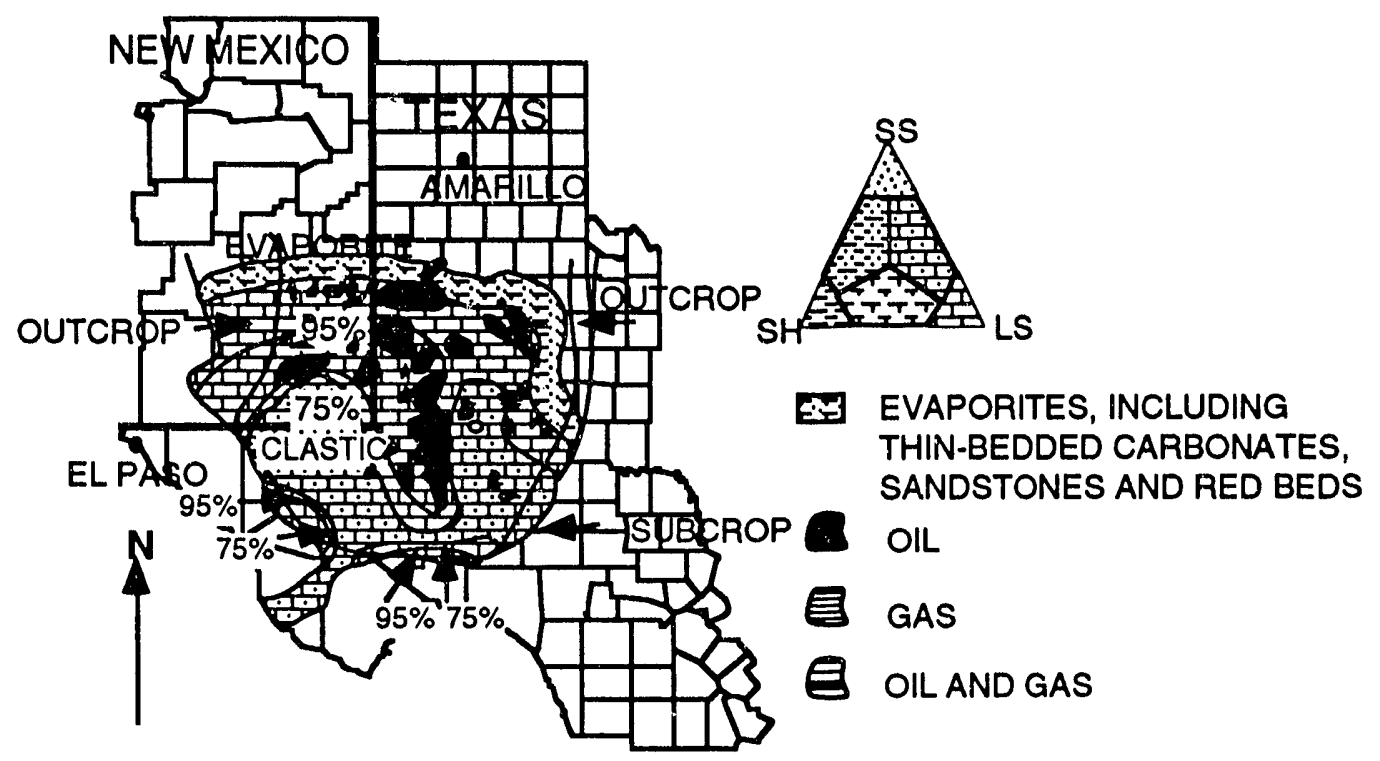

FIGURE 11. - Dominant lithofacies of Guadalupe Series. Oil and gas fields in reservoirs of the age are shown. Compiled and modified from Galley (1958), Dixon (1967), and Oriel et al. (1967) alterations by Hartman and Woodard.

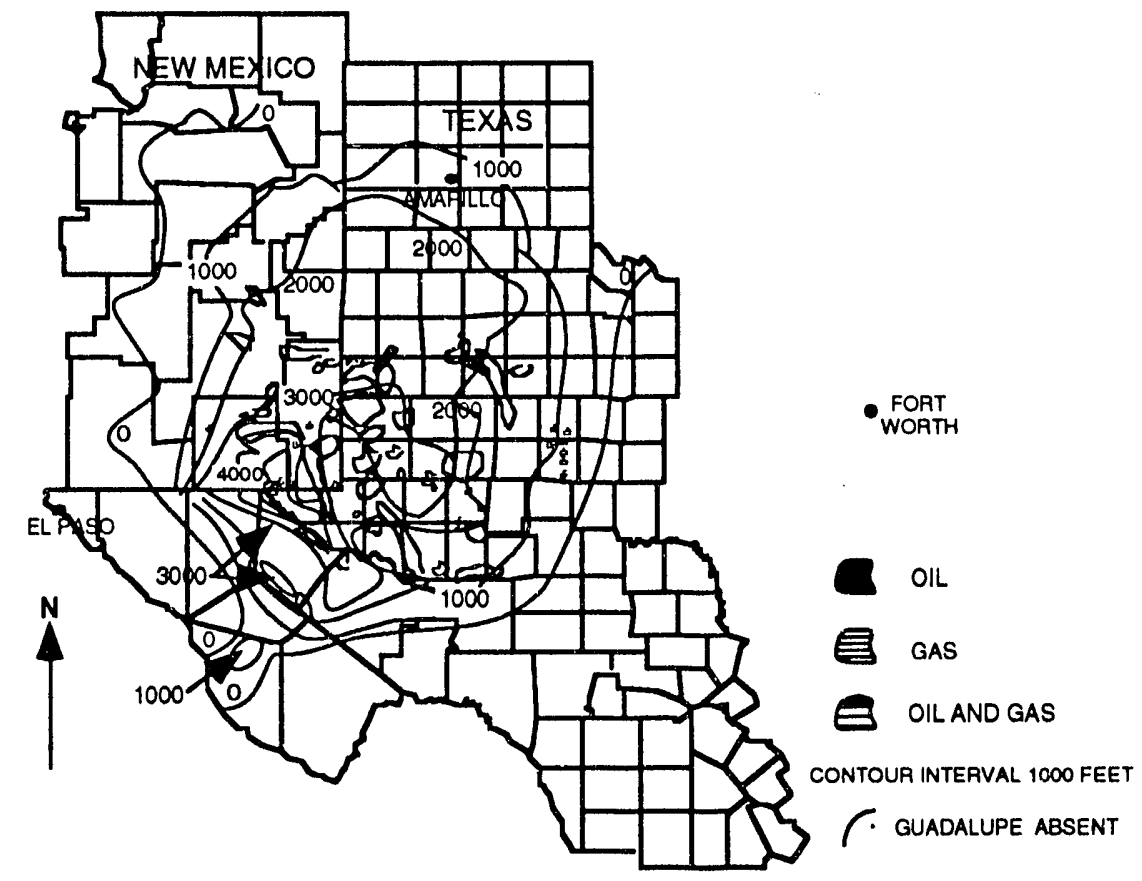

FIGURE 12. - Thickness of Guadalupe Series. Oil and gas fields in reservoirs of the age are shown. Compiled and modified from Galley (1958), Dixon (1967), and Oriel et al. (1967) alterations by Hartman and Woodard. 


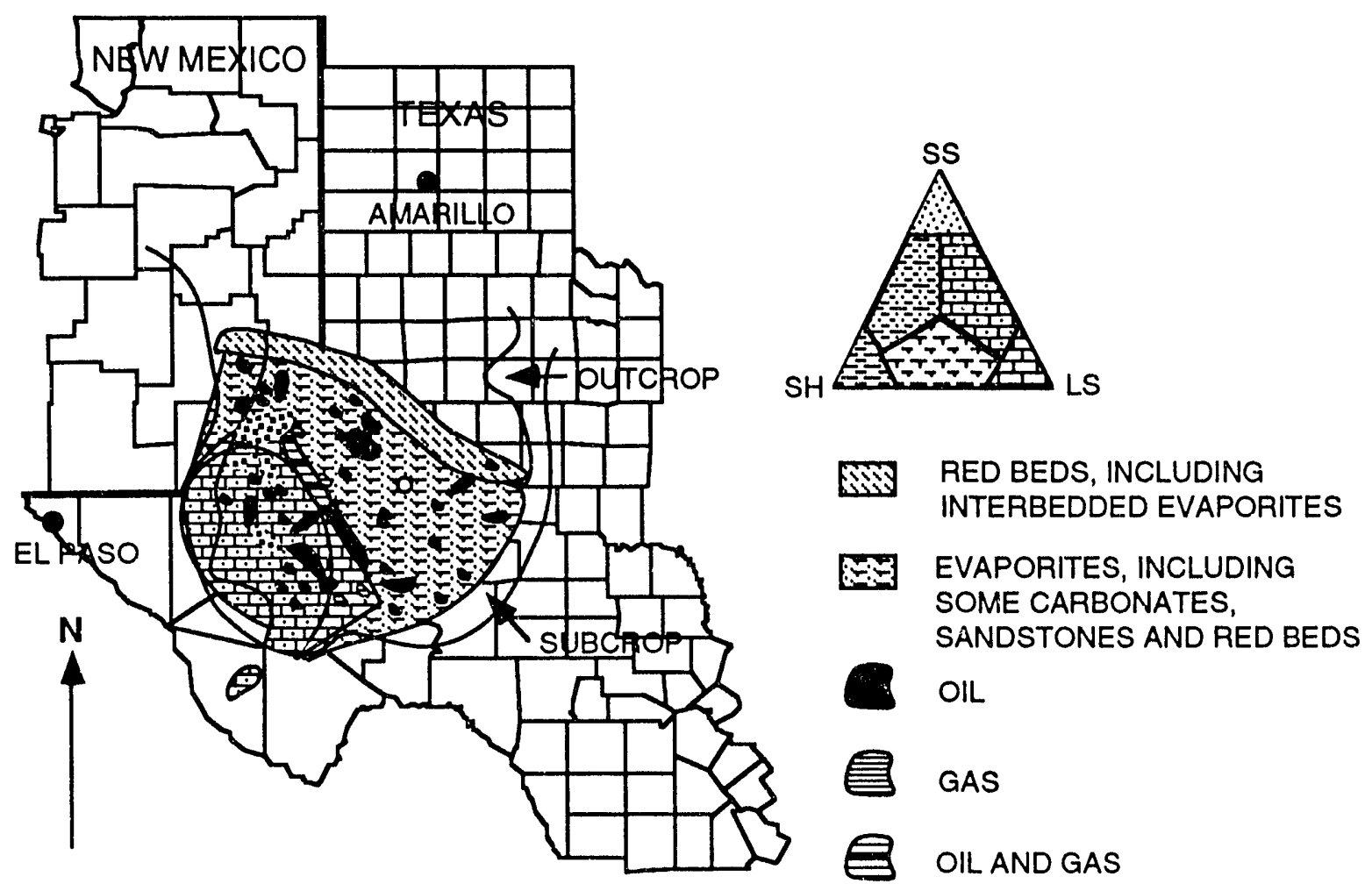

FIGURE 13. - Dominant lithofacies of upper Guadalupe Series. Oil and gas fields in reservoirs of the age are shown. Compiled and modified from Galley (1958), Dixon (1967), and Oriel et al. (1967) alterations by Hartman and Woodard.

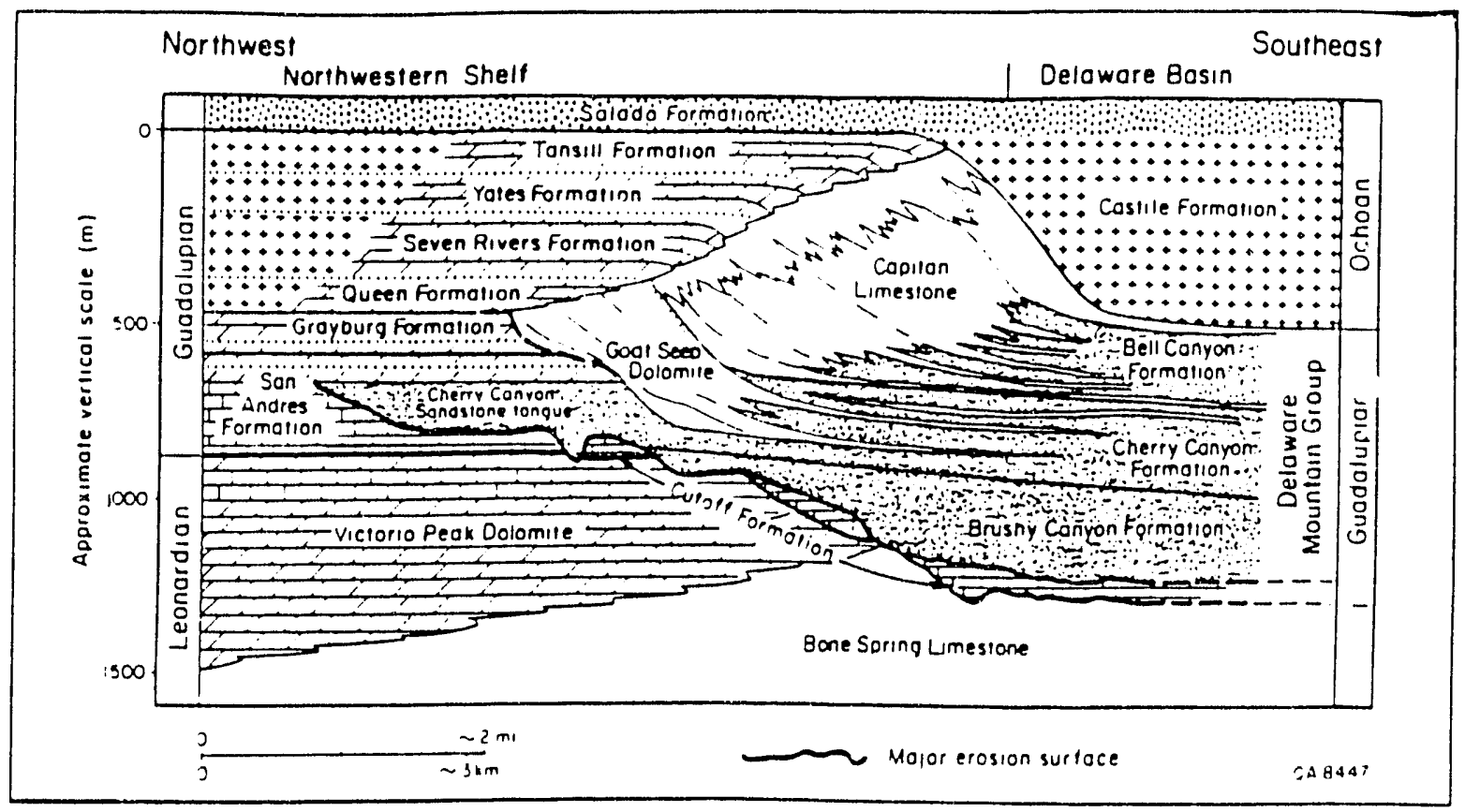

FIGURE 14. - Generalized Permian shelf-to-basin cross section of the Northwestern Delaware Basin. Modified from Fekete et al. (1986). 


\section{Bone Spring Formation}

The Maroon Cliffs Field in the Delaware Basin in Eddy County, New Mexico produces heavy oil from the Bone Spring Formation (Fig. 1). Reservoir rock for the Bone Spring is limestone (Crysdale and Schenk, 1990). The Bone Spring Formation is the basin limestone equivalent to the reef facies of the Abo formation in the Delaware Basin (LeMay, 1972). On the outcrop in New Mexico, the Bone Spring has a variety of facies from black basin limestone to reef to backreef limestone. The Bone Spring Formation may make up the entire Leonard Series in some locations. Thickness of this formation is greater than $1,500 \mathrm{ft}$ in the subsurface (Jones, 1953).

\section{Clear Fork Formation}

Three heavy oil fields produce from the Clear Fork Formation. These fields are located in the Midland Basin (Marholl Field in Dawson County, Texas and Wilson West Field in Lynn County, Texas) and the Northwestern Shelf of the Midland Basin (Ropesville Field in Hockley County, Texas) (Fig. 1). Reservoir rock in these fields are limestona and dolomites (Crysdale and Schenk. 1990). Oil production in Clear Fork carbonates is controlled by porosity development in the limestone and dolomite facies (Galloway, Ewing, Barrett, Taylor, and Debout, 1983).

\section{Guadalupe Series}

The Guadalupe Series reservoirs (Figs. 3 and 4) in the Permian Basin produce heavy oil from the Glorieta-San Angleo, San Andres, Grayburg, Seven Rivers, Yates and Tansill formations. Reservoir properties are listed in Appendix A for the various fields.

\section{Glorieta - San Angclo Formation}

The Coronet Field in Howard County, Texas produces from the Giorieta - San Angelo Formation. This field is located along the western edge of the Eastern Shelf of the Midland Basin (Fig. 1). The Glorieta is the dolomite equivalent of the sandy upper third of the San Angelo Formation (Figs. 11 and 12). Thickness of the Glorieta ranges from 50 to $180 \mathrm{ft}$. The San Angelo Formation is sandstone on the outcrop on the Eastern Shelf but it becomes more calcareous as it thickens westward into the Midland Basin (Jones, 1953). Reservoir rock is dolomite that has a 15-ft oil column (Crysdale and Schenk, 1990).

\section{San Andres Formation}

Ten heavy oil fields produce from the San Andres Formation. Two of these fields (Olson Field in Crockett County, Texas and Azalea West Field in Midland County, Texas) are in the Midland Basin of West Texas, and eight (Button Mesa South, Crossroads West, Jenkins, Mescalero and Ranger Lake Fields in Lee County, New Mexico; and Chisum, Leslie Spring and Tower Fields in Chaves County, New Mexico) are in the Delaware Basin of New Mexico (Fig. 1). Reservoir rock in these fields is dolomite, limestone, or a combination of dolomite, limestone, 
sandstone, and anhydrite (Figs. 11 and 14) (Crysdale and Schenk, 1990 and Jones, 1953). In the Midland Basin, the San Andres is light-colored crystalline dolomite that grades eastward to denser dolomite containing gray and green clastics and anhydrite. In the Delaware Basin of New Mexico, the San Andres is made up of fine to coarse crystalline dolomite, limestone, sandstone, and anhydrite. The San Andres has a thickness of $>650 \mathrm{ft}$ (Jones, 1953)

\section{Grayburg Formation}

Three heavy oil fields produce from the Grayburg Formation. They are in the Midland Basin (Olson Field, Crockett County, Texas), Delaware Basin (Wentz West Field, Pecos County, Texas), and Central Basin Platform (Hence Field, Ector County, Texas) of West Texas (Fig. 1). These reservoirs are dolomite, limestone, and sandstone (Figs. 13 and 14) (Crysdale and Schenk, 1990). The Grayburg in these areas is composed predominantly of dolomite, sandstone, anhydrite, and limestone. It reaches a thickness of $299 \mathrm{ft}$ (Jones, 1953).

\section{Seven Rivers Formation}

The Pyote Field, Ward County, Texas produces from the limestone Seven Rivers Formation. This field is located in the Delaware Basin of West Texas (Fig. 1). The Seven Rivers is composed of gypsum with some red sandstone, shale, limestone, and dolomite (Figs. 13 and 14) (Crysdale and Schenk, 1990; Jones, 1953).

\section{Yates Formation}

Four heavy oil fields (PCA, Magruder, Barber and Dirvene) produce from the Yates Formation. These fields are in the Delaware Basin of West Texas and New Mexico (Fig. 1). Reservoir rock for these fields is dolomite and limestone (Figs. 13 and 14) (Crysdale and Schenk, 1990). At the type locality of Yates Formation in the Yates Field, reservoir rock consists of $50 \mathrm{ft}$ of gray and red sand with large frosted quartz grains, thin beds of dolomite, and red and gray shale. In other locations where it is associated with reefing, it consists of gray sand interbedded with dolomite, but mostly red sand where it is associated with anhydrite and salt (Jones, 1953). A schematic of deposition of the red beds in relation to sea level is shown in Fig. 15 (Van Siden, 1958).

\section{Tansill Formation}

Two heavy oil fields, Maroon Cliffs and Parallel, produce from the Tansill Formation. These fields are in the Delaware Basin of New Mexico (Fig. 1). Reservoir rock for these fields is anhydrite, dolomite, sandstone, and siltstone (Figs. 13 and 14) (Crysdale and Schenk, 1990). The Tansill Formation consists of $123 \mathrm{ft}$ of primarily dolomite which includes a total of $17 \mathrm{ft}$ of sandstone and siltstone. Where it is associated with reefing, these facies are associated with anhydrite and salt beds (Jones, 1953). 


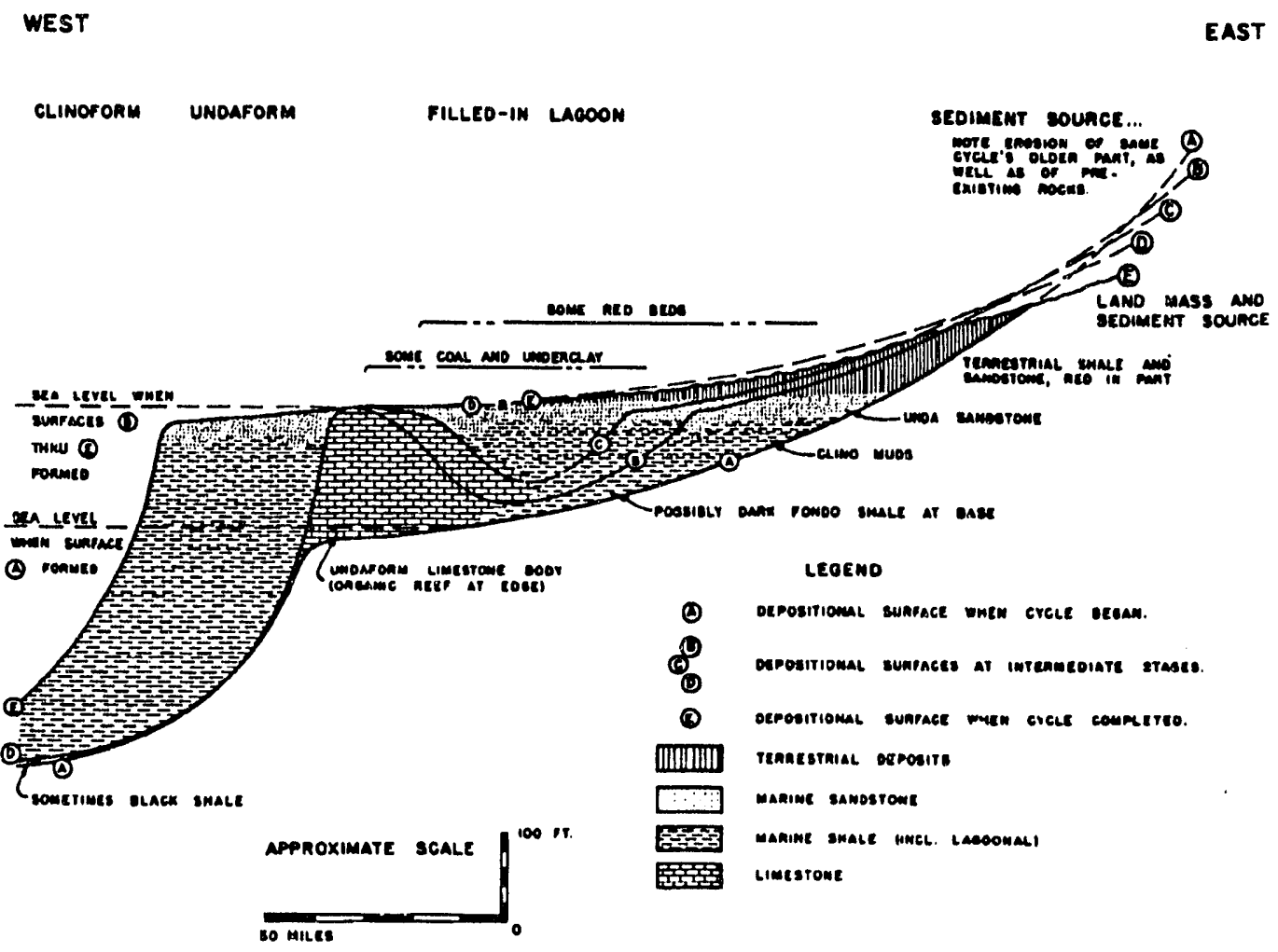

FIGURE 15. - Generalized deposition of the red beds in relation to sea level.

Mesozoic Era

Heavy oil within the Permian Basin occurs in Mesozoic Age formations. Within the Mesozoic Era, three periods of geologic time are represented, Triassic, Jurassic and Cretaceous. Heavy oil occurs within the early Cretaceous (Comanchean) Trinity Group.

\section{Trinity Group}

Toborg Field produces from the Trinity Group (undifferentiated) at the extreme southern end of the Central Basin Platform of the Permian Basin (Figs. 2 and 3). Toborg is the most important heavy oil field in the Permian Basin because it has produced $69 \%$ of the heavy oil produced in the Texas portion of the basin. Three sources of reservoir data give conflicting information on the API gravity $\left(19^{\circ}, 10^{\circ}\right.$ to $30^{\circ}$, and $\left.22^{\circ}\right)$ of oil produced from the Trinity reservoir in Toborg Field (Hance, Sharp and Nugent, 1990; Crysdale and Schenk, 1990; and Galloway, Ewing, Barrett, Taylor, and Debout, 1983). Toborg Field consists of multiple reservoirs in the Trinity Group. These reservoirs are poorly cemented, discontinuous fluvial sandstones that have high intergranular porosity and permeability. Some of the oil in these reservoirs is oil that migrated upward into the Trinity sandstones from underlying Permian oil reservoirs after the discovery of Yates Field. Protective and production casing were not cemented in early completions in Yates 
Field, causing Permian oil to migrate upward into shallow Trinity sandstones. Secondary recovery and close well spacing (2.5 acres) have resulted in an estimated $57 \%$ recovery efficiency (Galloway, Ewing, Barrett, Taylor, and Debout, 1983).

\section{Glen Rose Formation}

Five heavy oil fields (Billy Holland, Turney, Warcilaw, and Worth Evans Fields in Edwards County, Texas; Millspaugh Field in Crockett County, Texas) produce from the Glen Rose Formation. These fields are in the Midland Basin of West Texas (Fig. 1). Reservoir rock for these fields is limestone (Crysdale and Schenk, 1990). The Glen Rose is $900 \mathrm{ft}$ of partly shaley limestone with a few thin beds of anhydrite (Figs. 14 and 16) (Jones, 1953).

\section{Paluxy Formation}

Three heavy oil fields (Massie West and Parmer Fields in Val Verde County, Texas and Walt Field in Edwards and Val Verde County Texas) produce oil from the Paluxy Formation. These fields are in the Midland Basin (Fig. 1). Reservoir rock for these fields is sandstone (Crysdale and Schenk, 1990). The Paluxy consists of medium to coarse sand up to $80 \mathrm{ft}$ thick (Jones, 1953).

\section{Case Studies of Thermal Heavy Oil Projects \\ Devil's River Field Cyclic Steam Recovery Pilot Project}

In 1984, Petro Imperial Corporation, Dallas, Texas, conducted a cyclic steam recovery pilot project to evaluate the feasibility of recovering heavy oil from Devil's River Field in Val Verde County, Texas. This heavy oil reservoir is a stratigraphic trap in a shallow Paluxy Formation sand. Gas to operate the steam generator came from the 9,000 ft Strawn Formation gas reservoir in the field. During a pilot test to investigate the feasibility of cyclic steam to recover heavy oil in this reservoir, oil production in two wells was increased from 0.25 to 0.5 BOPD to a flow of 6 BOPD (Table 1). At the conclusion of the test, Petro Imperial was making plans to develop the 160-acre heavy oil reservoir (Vernetta, 1984). Attempts to determine the current status or reason for termination were unsuccessful.

\section{Holman Ranch Steamflood Heavy Oil Recovery Pilot Project}

In 1964, McWood Corp., Abilene, Texas, conducted a steamflood heavy oil recovery pilot project in Holman Ranch Field in Edwards County, Texas. The heavy oil reservoir is a shallow Glen Rose Formation sandstone. The project used a central steam injection well with four producing wells in a 5-spot pattern. The first attempt to recover heavy oil from the reservoir by steamflood ended in failure. The failed attempt was caused by early breakthrough in an old well completed in 1947 with nitroglycerine stimulation. When attempting to drill a replacement well, a blowout occurred while drilling into a live steamflood pattern. Oil/water emulsion problems 


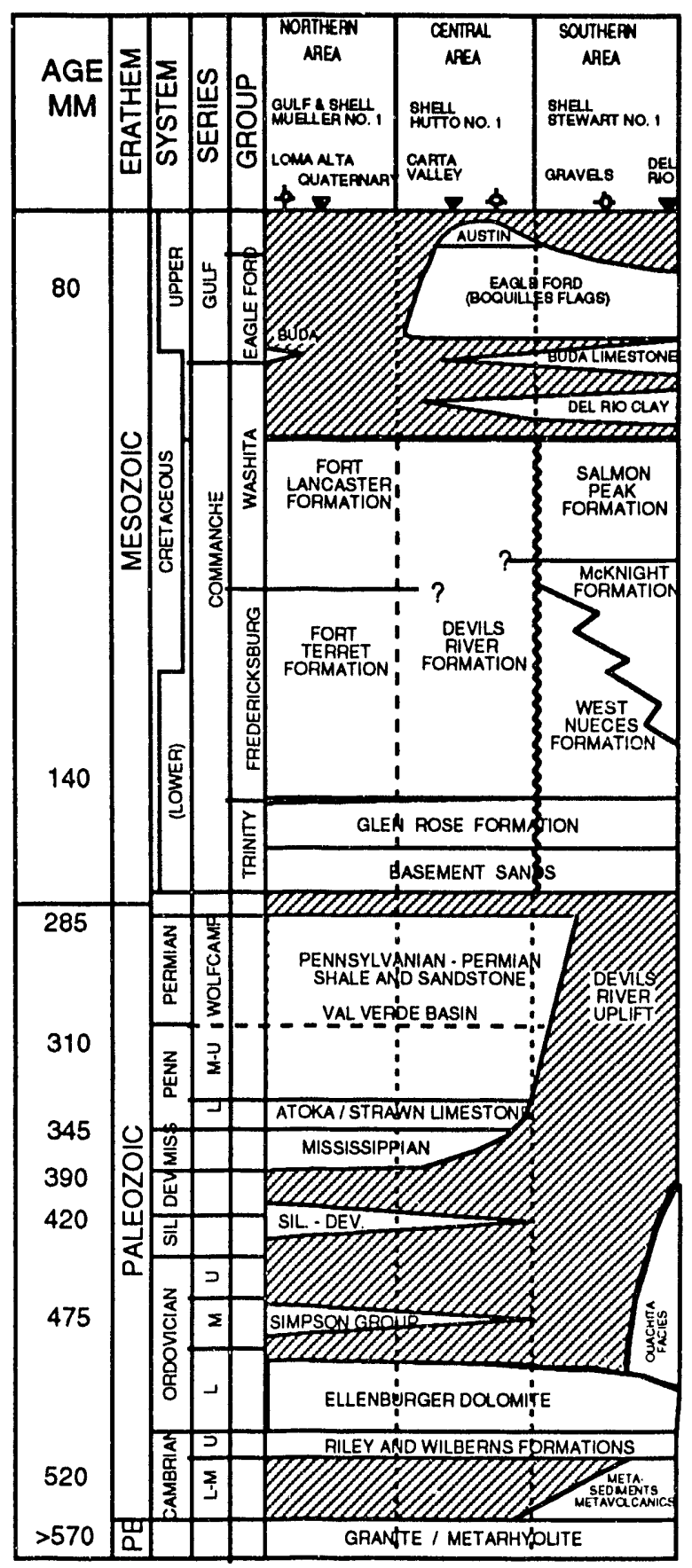

FIGURE 16. - Composite Stratigraphic sections for Devil's River uplift-southern Val Verde Basin, Texas (Webster 1980). 
TABLE 1

\section{Devil's River Field Cyclic Steam Recovery Pilot Project \\ By Petro Imperial Corporation, Val Verde County, Texas}

\begin{tabular}{lr}
\hline Areal Extent, acres & 160 \\
Producing formation & Paluxy \\
Lithology of reservoir & Sand \\
Depth, ft & $300-350$ \\
Pay Thickness, ft & 20 \\
Porosity, \% & 18 to 30 \\
Permeability, mD & $200-900$ \\
Oil saturation (\%) & 65 \\
Oil in Place, bbl/acre-ft & $800-1300$ \\
Reservoir Temperature, ${ }^{\circ} \mathrm{F}$ & 50 \\
Gravity of Oil, ${ }^{\circ} \mathrm{API}$ & $16-19$ \\
Oil Production, Natural, BOPD & $0.25-0.5$ \\
Oil Production After Steum Stimulation, BOPD & 6 \\
Oil Viscosity: cP at 70 ${ }^{\circ} \mathrm{F}$ & 480 \\
$\quad$ cP at $100^{\circ} \mathrm{F}$ & 165 \\
Estimated recovery factor, \% & $10-40$ \\
Time of steam stimulation, hours & 15 \\
Number of wells stimulated & 2 \\
Number of wells in pilot project & 11 \\
Steam injection pressure, psi & 300 \\
Size of steam generator, MMBtu/hr & 2 \\
Injection pattern, spot & 5
\end{tabular}

experienced during thermal recovery were overcome by chemical treatment of produced emulsion. The second attempt at recovering heavy oil in a second pattern by steamflood stimulation in Holman Ranch Field was successful. Maximum daily oil production in the second attempt was approximately 119 BOPD, Table 2. At the end of the second pilot project, McWood was considering plans to test the feasibility of recovering heavy oil in this field by cyclic steam injection (Emery, 1966). Attempts to determine the current status or reason for termination were unsuccessful.

\section{CONSTRAINTS}

Heavy oil is successfully being produced by cyclic steam, steamflood and in situ combustion from principally thick unconsolidated or friable reservoirs in California, Canada, and Venezuela. In the United States, TEOR is the largest enhanced oil producing technology contributing $69 \%$ or 454,000 BOPD of the 656,700 BOPD total U. S. EOR production in 1990 (Moritis, 1990). The consolidated and the thinner laminated nature of the heavy oil bearing formations in the Permian Basin limits economic production. The oil in the Permian Basin is principally paraffinic unlike the asphaltic California heavy crudes. Paraffinic crudes command a higher price than asphaltic oils of the same gravity. Within the Permian Basin, there are deeper hotter reservoirs with significant solution gas in the heavy oil that produce on primary or are easily waterflooded even though they are consolidated. 
TABLE 2

\section{Holman Ranch Field Steamflood Recovery Pilot Project By McWood Corp., Edwards County, Texas}

\begin{tabular}{|c|c|}
\hline \multirow{2}{*}{\multicolumn{2}{|c|}{$\begin{array}{l}\text { Areal Extent of pilot project, acres } \\
\text { Well spacing: acres }\end{array}$}} \\
\hline & \\
\hline Producing formation & Glen Rose \\
\hline Lithology of reservoir & Sandstone \\
\hline $\begin{array}{l}\text { Depth, ft } \\
\text { Pay thickness, ft }\end{array}$ & 550 \\
\hline $\begin{array}{l}\text { Pay thickness, ft } \\
\text { Average porosity, \% }\end{array}$ & $5-15$ \\
\hline $\begin{array}{l}\text { Average porosity, \% } \\
\text { Permeability, mD }\end{array}$ & 31.4 \\
\hline $\begin{array}{l}\text { Permeability, mD } \\
\text { Oil saturation, \% }\end{array}$ & $12-2,100$ \\
\hline Water saturation, $\%$ & $50.8-77.3$ \\
\hline Gravity of oil, ${ }^{\circ} A \mathrm{M}$ & 12 \\
\hline Viscosity of oil, cP at $70^{\circ} \mathrm{F}$ & 15.2 \\
\hline Formation volume Factor & 1160 \\
\hline Initial oil production, Natural, BOPD & 1.015 \\
\hline Steam generator, Btu/hour & $0.5-2$ \\
\hline Steam injection temperature, ${ }^{\circ} \mathrm{F}$ & $11,600,000$ \\
\hline Steam injection pressure, psi at surface & 500 \\
\hline Maximum heavy oil production during pilot project, BOPD for all wells & 900 \\
\hline 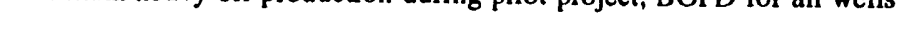 & 119 \\
\hline
\end{tabular}

\section{Refining and Transportation}

The transportation network in the Permian Basin is dominated by the large volume of light oil produced in the basin. Significant heavy oil above current production levels could be blended to the current light oil streams and pumped to refineries on the Gulf Coast. Currently, Californian heavy oil and Alaskan North Slope oil (28 API gravity) is transported as blended oil from California by the All-American pipeline to the Basin (Fig. 17). The pipeline network ships oil to refineries in the Permian Basin, the Gulf Coast (Gill, 1990; Williams, 1990) and the Midwest. The alternative transport route for California heavy oil has been by tanker transport through the Panama Canal to the U.S. Gulf Coast. The Permian Basin has an extensive infrastructure supporting extensive primary production, aging and rapidly declining waterfloods, and a growing number of $\mathrm{CO}_{2}$ enhanced oil recovery projects conducted as miscible floods to recover light oil. This oil supplements declining oil production from waterflood operations. The light oil in the Permian Basin has become more sour during waterflood operations conducted over the past 40 years. Most refineries in the basin are designed to process light crude oils. Addition of heavy oil would significantly impact operation since they have limited capability to process heavy ends (Thrash, 1990; Thrash, 1991). A separate heavy oil gathering system with heated pipelines to transport oil to a suitable refinery would require much larger heavy oil production which is not anticipated or justified based on the volume of heavy oil resources in the Permian Basin. 


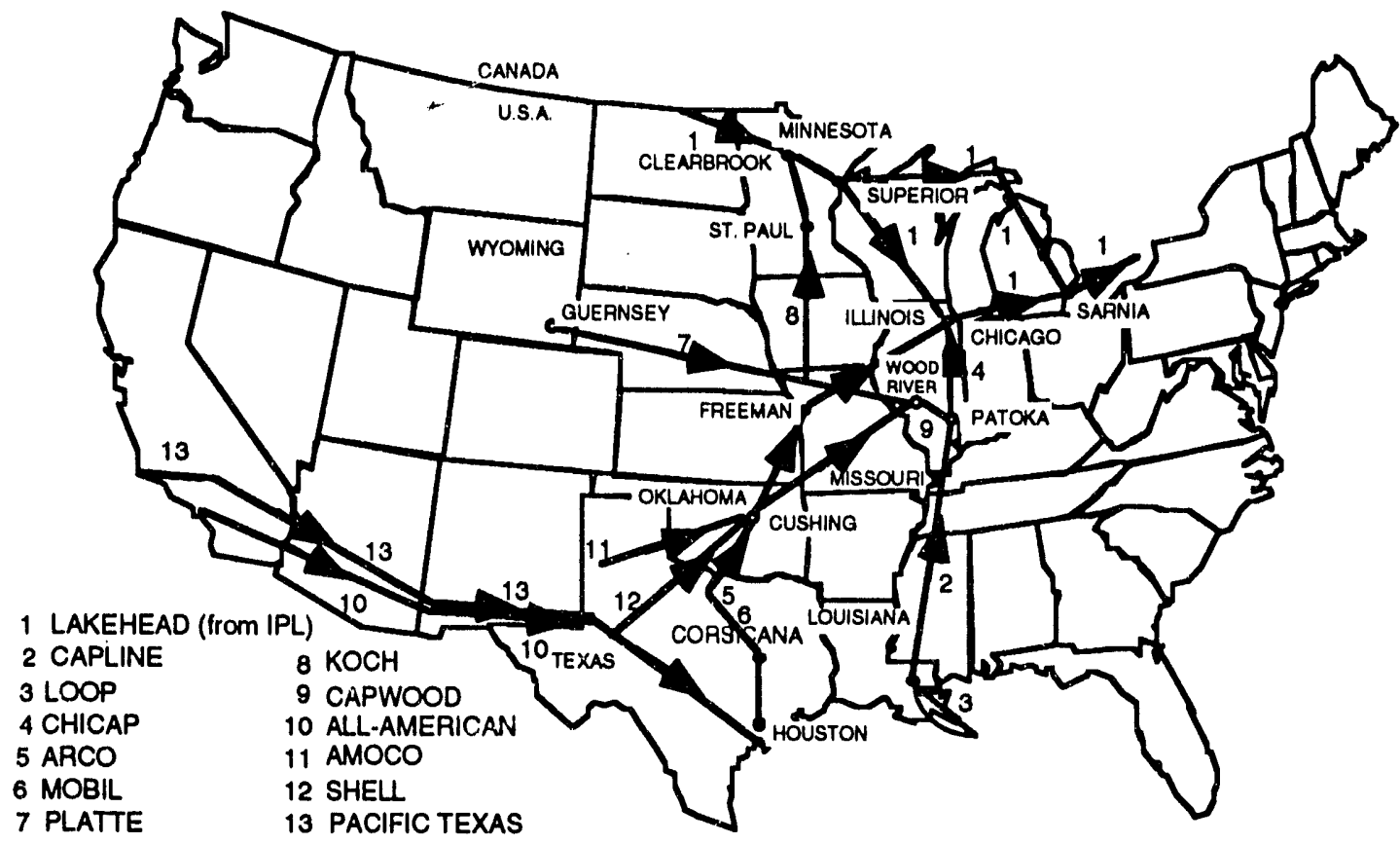

FIGURE 17. - Pipelines carrying heavy oil as a blend into and out of the Permian basin to the Midwest and Gulf Coast.

\section{Environmental}

The Permian Basin typifies the U.S. oil patch, and oil is a major industry of the area. Increasing awareness of the environment is becoming incorporated into the petroleum industry's mode of doing business. The arid nature of the Permian Basin limits fresh water use for other than domestic and agricultural applications. Since anticipated thermal oil recovery operations will be minimal, the shortage of water will not be significantly impacted by TEOR demand for fresh water. The air quality of the region is significantly better than that of sections of California, but the State of Texas has not issued a permit for a steam generator other than gas fired since 1986 (Bergrath, 1991). Air and water quality are a concern as both Texas and New Mexico environmental regulations become more stringent and trend toward limits similar to those of California.

\section{Economics of Thermal Heavy Oil Production}

The economics of heavy oil recovery in the Permian Basin was analyzed based on the oil recovered, the reported duration of the project, and the 1990 cost of thermal operations as obtained from the assessed evaluation of thermal (steam) operations in Kern County, California (Maples, 1990, Table 3 and Table 4; Sarathi and Olsen, 1992). Numerous operators produce heavy oil on 
TABLE 3

Thermal EOR operating costs

(Maples, 1990-91)

\begin{tabular}{rrr}
\hline Well depth. A & NEW PRODUCING WELL COSTS & Iniectors. \\
\hline $0-250$ & 37,000 & \\
$251-750$ & 73,000 & 30,000 \\
$751-1,250$ & 89,000 & 60,000 \\
$1,251-1,750$ & 121,000 & 100,000 \\
$1,751-2,250$ & 160,000 & \\
$2,251-2,750$ & 200,000 & \\
$2,751-3,250$ & 240,000 & \\
\hline
\end{tabular}

TABLE 4

Yearly thermal steam operating cost ranges within each field/well (Maples, 1990-91)

\begin{tabular}{|c|c|c|}
\hline Field & Cyclic steam. \$ & Steamflood. s \\
\hline $\begin{array}{l}\text { Cymric } \\
\text { Kern River } \\
\text { Midway-Sunset }\end{array}$ & $\begin{array}{l}20,000 \\
20,000 \\
18,000\end{array}$ & $\begin{array}{l}27,500 \\
27,000 \\
26,000\end{array}$ \\
\hline \multicolumn{3}{|c|}{$\begin{array}{c}\begin{array}{c}\text { Steam generator maintenance costs/BTU barrel equivalent of oil burned, in } \\
\text { Gallfired }=0.20\end{array} \\
\text { Gas fired }=0.10\end{array}$} \\
\hline
\end{tabular}

primary or by waterflooding deeper reservoirs. Because heavy oil is more viscous than light oil, the mobility ratios in waterfloods will be adverse. Operators waterflooding heavy oil reservoirs are probably operating at a lower oil to water ratio than those waterflooding light oils, and thus their operating costs are anticipated to be higher per barrel of oil produced.

For shallow heavy oil operations, primary production per well usually classifies these wells as stripper wells ( $<10 \mathrm{BOPD})$. Since these operations continue, wells were deemed marginally economical and they were not considered in this analysis because the volume of oil produced is small and the recovery efficiency is usually less than 5\%. Tabular listing of the royalties and tax liabilities within New Mexico and Texas are shown in Table 5. Operating costs for Kern County, California thermal operations in 1990 ate shown in Table 4. These average costs (as assembled by Maples, the Kern County, California Assessor for 1990) are based on proprietary data supplied by thermal operators. There is reason to believe that none of the thermal projects listed in this report would be operating after the 1986 drop in oil prices, even though the paraffinic crude they produced was selling for as much as West Texas Intermediate (WTI) crude oil (discounted 15 cents 


\section{TABLE 5}

\section{Comparisons of economic factors affecting oil production from Mrdcontinent states}

\begin{tabular}{|c|c|c|c|c|c|c|c|c|}
\hline & Kansas $\mathbf{a}$ & Oklahoma ${ }^{2}$ & Missourib & $\begin{array}{c}\text { Newa } \\
\text { Mexico }\end{array}$ & Illinois ${ }^{a}$ & Texas ${ }^{2}$ & Colo. ${ }^{2}$ & $\begin{array}{l}\text { Northa } \\
\text { Dakota }\end{array}$ \\
\hline $\begin{array}{l}\text { Land owner royalty, \% } \\
\text { Land surface disruption, }\end{array}$ & $\begin{array}{c}12.5 \\
\text { Site } \\
\text { specific }\end{array}$ & $\begin{array}{c}12.5 \\
\text { Site } \\
\text { specific }\end{array}$ & $\begin{array}{c}12.5 \\
\text { Site } \\
\text { specific }\end{array}$ & $\begin{array}{c}12.5 \\
\text { Site } \\
\text { specific }\end{array}$ & $\begin{array}{c}12.5 \\
\text { Site } \\
\text { specific }\end{array}$ & $\begin{array}{c}12.5 \\
\text { Site } \\
\text { specific }\end{array}$ & $\begin{array}{c}12.5 \\
\text { Site } \\
\text { specific }\end{array}$ & $\begin{array}{c}12.5 \\
\text { Site } \\
\text { specific }\end{array}$ \\
\hline $\begin{array}{l}\text { Direct state tax, \% } \\
\text { Emergency school tax }\end{array}$ & $4.33^{\mathrm{c}}$ & $7.0^{d}$ & None & $\begin{array}{l}3.75^{\mathrm{d}} \\
3.15^{\mathrm{c}}\end{array}$ & None & $4.6^{d}$ & $2-5 \mathbf{e}$ & $5^{\mathrm{c}, \mathrm{f}}$ \\
\hline \multicolumn{9}{|c|}{ State Severance Production tax } \\
\hline Productivity & $\begin{array}{l}\text { 1. Variable } \\
\text { stripper }\end{array}$ & None & Noneg & None & None & None & $\begin{array}{l}\text { Stripper } \\
\text { wells }\end{array}$ & $\begin{array}{l}\text { 1. Variable } \\
\text { stripper }\end{array}$ \\
\hline Vintage & $\begin{array}{l}\text { 2. New oil } \\
\& \text { gas }\end{array}$ & None & & & & None & None & 2. New oil \\
\hline Other & \multicolumn{3}{|c|}{$\begin{array}{l}\text { 3. Tertiary oil incremental prod. } \\
\text { Secondary \& tertiary }\end{array}$} & & $\begin{array}{l}50 \% \text { for } \\
\text { EOR }\end{array}$ & None & & 3. Workovers \\
\hline Ad Valorum Tax & Yes ${ }^{h}$ & None & None & Yes $^{h}$ & Yes & Yes & Yes & None \\
\hline Corporate Income Tax & Yes $^{\mathrm{i}}$ & Yes $^{h}$ & Yes & Yesi & Yes & None & Yes & Yes \\
\hline Corporate Franchise Tax & Yes $^{k}$ & Yes 1 & None & Yesj & Yes & Yes $^{1}$ & None & $\begin{array}{l}\text { Flat } \\
\$ 150 / \mathrm{yr}\end{array}$ \\
\hline $\begin{array}{l}\text { Effective Average Tax Rat } \\
\% \text { on oil } \& \text { gas produc }\end{array}$ & $\begin{array}{l}\text { ate, } 9.7 \\
\text { uction }\end{array}$ & 7.4 & Variable & 8.9 & 1.3 & 8.4 & 6.4 & 10.2 \\
\hline
\end{tabular}

a Kansas Inc., Strategic Analysis of the Oil and Gas Industry in Kansas, Arthur D. Little, Inc., Cambridge, Mass., April 1990.

b Personal communication with K. Deason, Missouri Dept. of Natural Resources, and S. Evers, Missouri Dept. of Revenue, July 1990.

c Gross Lease Revenue (N.B.- Does not discount transportation and marketing costs).

d Gross Lease Revenue less Marketing and Transport Costs.

e Less than $\$ 25,000$ at $2 \%, \$ 25,000-\$ 100,000$ at $3 \%, \$ 100,000-\$ 300,000$ at $4 \%, \$ 300,000$ and over at $5 \%$ on corporate/individual oil/gas revenues.

f An extraction tax is assessed at the rate of $6.5 \%$ for old wells and $4 \%$ for new wells.

8 Each state is attempting to mitigate declining oil production and declining revenues to the state and have or are considering economic incentives for enhanced oil recovery.

h Ad valorum tax levied on the economic value of each producing unit. Appraisal value calculated by applying present worth factor to future revenue to derive a net worth for each lease.

i Tax basis derived from apportioned revenue derived within siate as determined by three factor formula equally weighted. A two factor formula is available for qualifying companies. Rates are $\$ 0-\$ 25,000$ at $4.5 \%,>25,000$ at $6.75 \%$.

j Separate accounting for oil and gas incorse on all taxable income.

$k$ Of shareholder equity $0.1 \%$, minimum of $\$ 20$ and maximum of $\$ 2,500$.

1 Of business and investment capital $0.125 \%$, minimum of $\$ 10$ and maximum of $\$ 20,000$. 
per API gravity point). These thermal projects had low oil production rates. Inquiries in August 1991 indicated that Permian Basin heavy oil producers were selling their heavy oil at the posted price for WTI less the penalty for sulfur and API gravity (about $\$ 3$ under that for WTI). This is significantly more than the posted price for Kern County heavy oil, as shown in Fig. 18. The ratio of posted crude oil prices for Kern River and other oils are shown in Fig. 19. Kern River oil posted price has averaged about two-thirds of the price of WTI over the past decade (Maples, 1991; Oil \& Gas J., Statistics, 1984-1992).

\section{CONCLUSIONS}

The Permian Basin of West Texas and Southeastern New Mexico is a minor heavy oil producing basin and does not seem destined to increase its role in supplying significant heavy oil. Toborg Field in Pecos and Crockett Counties, Texas, is the field which is reported to be the largest producer of heavy oil but the field should not be considered as all heavy oil on about $500 \pm$ acres The reason for the high recovery from this field is because it is a low gravity oil with significant solution gas.. Conflicting reports on the API gravity of the oil $\left(22^{\circ}, 19^{\circ}, 20^{\circ}\right.$ and $10^{\circ}-30^{\circ}$ and the acreage producing heavy oil) indicate that all the oil assigned as heavy oil may not fall within the definition of heavy oil (Group, 1981). Toborg Field produces from multiple fluvial sandstone reservoirs within the Trinity Group as commingled production. Permian Age carbonate reservoirs dominate the heavy oil reservoirs in the Permian Basin, but they have only produced $40 \%$ of the heavy oil in this basin.

Thermal operations in fractured carbonates for recovery of heavy oil has recently generated renewed interest in laboratory and modeling and since worldwide this is a sizable resource (Briggs, 1992). Recovery from most heavy oil carbonates is very low, $<5 \%$..

Thermal oil recovery methods to produce the heavy oil in the Permian Basin are not anticipated to recover significant heavy oil from the consolidated formations because steam has not proven to be economic in most areas where it has been attempted in tight consolidated formations. Infill drilling can be expected to increase heavy oil recovery in the Permian Basin thus improving the low cumulative heavy oil production on primary and from waterflooding. Environmental problems due to TEOR operations to produce heavy oil are not anticipated for this area because the heavy oil resource is not large enough to warrant implementation of significant TEOR projects. The discovery of a large heavy oil field in the Permian Basin is unlikely because the area is in a mature stage of exploration and development. No further investigation of the Permian Basin heavy oil resource is recommended. 


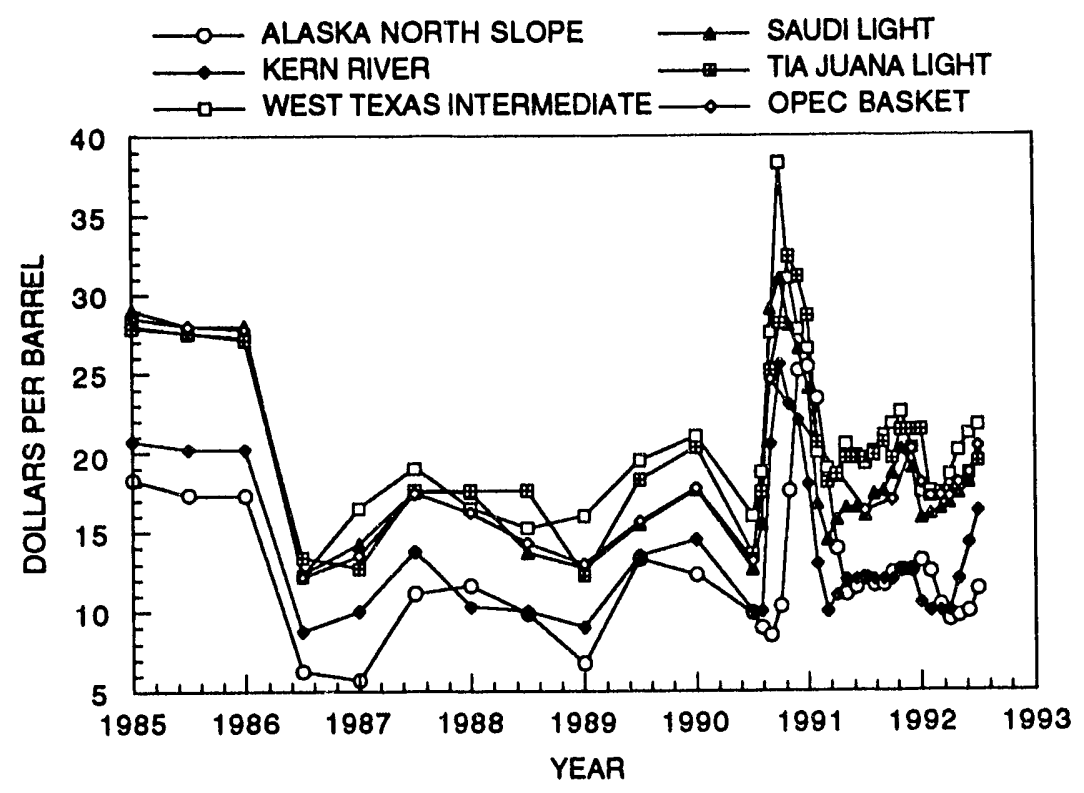

FIGURE 18. - Comparison of average oil price of benchmark crude oils.

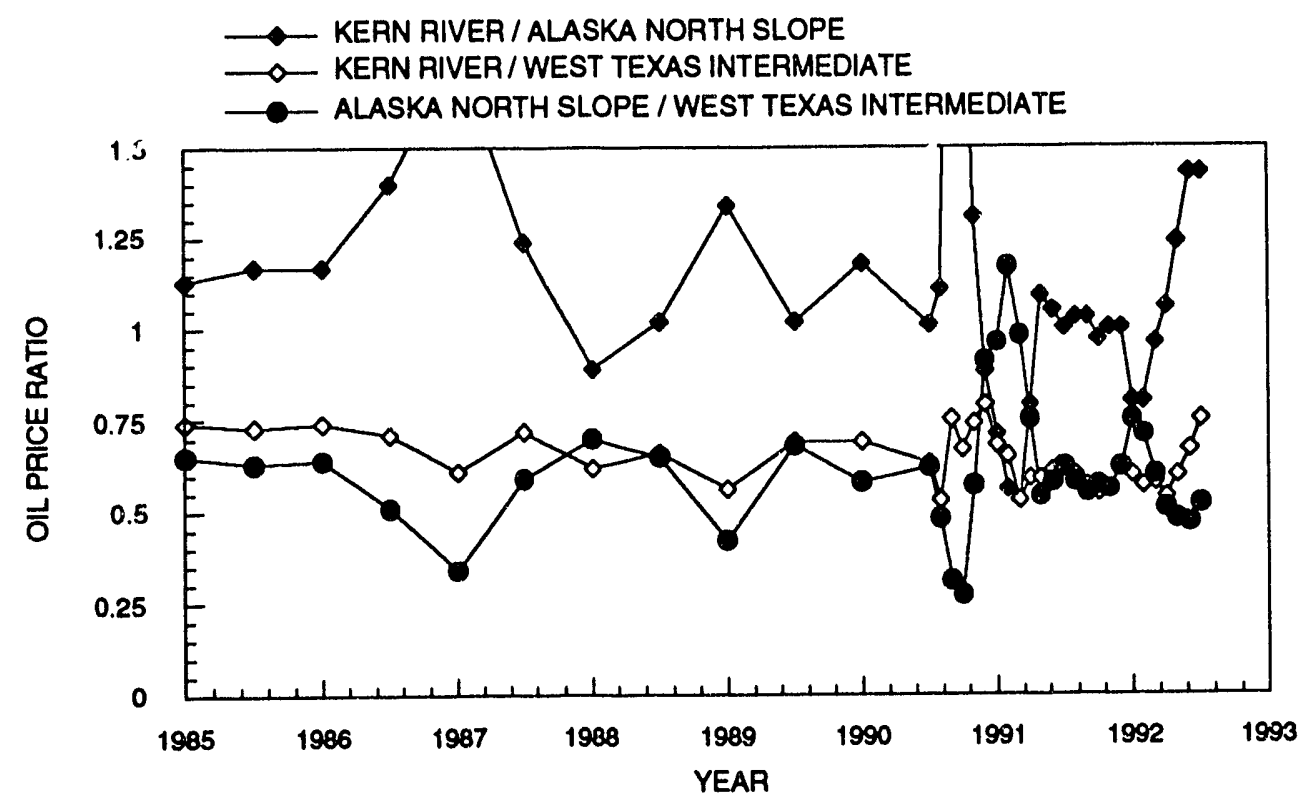

FIGURE 19. - Ratio of oil prices for benchmark heavy and light crude oils. 
The database in the appendix of this report lists average data heavy oil reservoirs and heavy oil reservoirs in excess of 1 million barrels of OOIP. No viscosity data is included because of the lack of available data. Only the database with $>1$ million barrels OOIP warranted completion of the database and research to find reservoir parameters.

\section{ACKNOWLEDGMENTS}

This work was sponsored by the U.S. Department of Energy under cooperative agreement DE-FC22-83FE60149 as project SGP37. The authors thank E. B. Ramzel of NIPER for the database development; Associated Western University Student Interns, Everett Taylor, Robert Pendergrass, Johnathan Grigsby and Heather Horstman for preparation of the figures; and M. K. Tham and A. Strycker of NIPER, and Bill Peters and Tom Reid of the DOE Bartlesville Project Office for their critical reviews. The authors wish to thank the staff of the geologic surveys of New Mexico and Texas and the regulatory agencies of these states for their cooperation in helping to define the potential of heavy oil recovery in the Permian Basin.

\section{BIBLIOGRAPHY}

Asquith, G. B. and J. F. Drake: Depositional History and Reservoir Development of a Permian Fistulipora-Tubiphytes Bank Complex, Blalock Lake East Field, West Texas, in Carbonate Petroleum Reservoirs. Eds. Roehl, P. O. and P. W. Choquette, Springer-Verlag, NY, NY, 1985, pp. 309-318.

Bergrath, S: Personal Communications, Enercap Corp., Houston, TX, October 1991.

Bain, A. and L. S Land: San Andres Carbonates in the Texas Panhandle: Sedim .tation and Diagenesis Associated with Magnesium.Calcium-Chloride Brines, Texas Bureau of Economic Geology, UT Austin, Texas, Report of Investigations No. 121, 1982, p. 48.

Borer, J. M. and P. M. Harris: Lithofacies and Cyclicity of the Yates Formation, Permian Basin: Implications for Reservoir Heterogeneity, AAPG Bulletin No. 75, April 1991, pp. 726-779.

Briggs, P. J., D. L. Beck, C. J. J. Black and R. Bissell: Heavy Oil From Fractured Carbonate Reservoirs, SPE Reservoir Engineering, May 1992, pp. 173-179.

Budnick, R. T. and D. Smith: Regional Stratigraphic Framework of the Texas Panhandle, in Gustavson, T. C. et al, Geology and Geohydrogology of the Palo Duro Basin, Texas Panhandle, Texas Bureau of Economic Geology, UT Austin, Texas, Circular 82-7, 1982, pp. 38-86.

Chuber, S. and W. C. Pusey: Productive Permian Carbonate Cycles, San Andres Formation, Reeves Field, West Texas, in Carbonate Petroleum Reservoirs. Eds., P. O. Roehl and P. W. Choquette, Springer-Verlag, NY, NY, 1985, pp. 289-308.

Clark, L: Personal Communication, Independent Oil Producers' Agency, Taft, California, November 1991.

Crysdale, B. L. and C. J. Schenk: Heavy Oil Resources of the United States, US Geologic Survey Bulletin 1885, U.S. Geological Survey, 1990. 
Cys, J. M. and S. J. Mazzullo: Depositional and Diagenetic History of a Lower Permian (Wolfcamp) Phylloid-Algal Reservoir, Hueco Formation, Morton field, Southeastern New Mexico, in Carbonate Petroleum Reservoirs. Eds., P. O. Roehl and P. W. Choquette, Springer-Verlag, NY, NY, 1985, pp. 277-288.

Debout, D. G., F. J. Lucia, C. R. Hocott, G. E. Fogg and G. W. Vander: Characterization of the Grayburg Reservoir, University Lands Dune Field, Crane County, Texas, Texas Bureau of Economic Geology, Report of Investigations No. 168, UT Austin, Texas, 1987 p. 98.

Dixon, G. H.: Paleotectonic Investigations of the Permian System in the United States, Northeastern New Mexico and Texas-Oklahoma Panhandles, U.S. Geologic Survey, Prof. Paper No. 515-D, 1967, pp. 61-80.

Emery, M. N: Small Steam Flood Works for Independent, Petroleum Engineer, 1966, pp. 63-67.

Fekete, T. E., E. K. Franseen and L. C. Pray: Deposition and Erosion of the Grayburg Formation (Guadalupian, Permian) at the Shelf-to-Basin Margin, Western Escarpment, Guadalupe Mountains, Texas, in SEPM Permian Basin Section, Lower \& Middle Guadalupian Facies, Stratigraphy and Reservoir Geometrics, San Andres/Grayburg Formations, Guadalupe Mountains, New Mexico \& Texas, Field Trip (Midland, Texas, 86/10/10-11) Guidebook, PBS-SEPM Publication No. 86-25, 1986, pp. 69-81.

Fracasso, M. A. and S. D. Hovorka: Cyclicity in the Middle Permian San Andres Formation, Palo Duro Basin, Texas Panhandle, Texas Bureau of Economic Geology, UT Austin, Texas, Report of Investigations No. 156, 1986.

Gaines, R. B., W. W. Collier, R. A. Diemer, W. R. Gibson, H. A. Miller and L. D. Robbins: Oil and Gas Developments in West Texas and Eastern New Mexico in 1981, AAPG Bulletin No. 66, November 1982, pp. 1869-1878.

Galley, J. E.: Oil and Geology in the Permian Basin of Texas and New Mexico, in Habitat of Oil, Weeks, L. G. Ed., AAPG Special Publication 5802, 1958, pp. 395-446.

Galloway, W. E., T. E. Ewing, C. M. Garrett, N. Tyler and D. G. Debout: Atlas of Major Texas Oil Reservoirs, Texas Bureau of Economic Geology, UT, Austin, Texas, 1983.

Gariet, Chat:: Personal communication, Bureau of Economic Geology, Austin, TX, August 3, 1992.

Gill, D: Kern County, Oil \& Gas Investor, August 1990, pp. 14-27.

Group of Experts: UNITAR Proposal for the Definition of Heavy Crude and Tar Sands and Addendum, Second International Conference on Heavy Oil and Tar Sands, Caracas, Venezuela, February 1981.

Hance, K., J. Sharp and J. E. Nugent: Railroad Commission of Texas, Oil and Gas Division Annual Report 1989, v. 1., Oil and Gas Division State of Texas, Austin, Texas.

Hartman, J. R. and L. R. Woodward: Future Petroleum Resources in Post-Mississippian Strata of North, Central, and West Texas and Eastern New Mexico, in Future Petroleum Provinces of the United States - Their Geology and Potential. Ed., I. H. Cram. AAPG Memoir 15, v. 1, 1971, pp. 752-800. 
Hills, J. M: Sedimentation, Tectonism, and Hydrocarbon Generation in Delaware Basin, West Texas and Southeastern New Mexico, AAPG Bulletin No. 68, March 1984, pp. 250-267.

James, A. D.: Producing Characteristics and Depositional Environments of Lower Pennsylvanian Reservoirs, Parkway-Empire South Area, Eddy County, New Mexico, AAPG Bulletin No. 69, 1985, pp. 1043-1063.

Jones, T. S.: Stratigraphy of the Permian Basin of West Texas, West Texas Geological Society, 1953.

Kansas Inc.: Strategic Analysis of the Oil and Gas Industry in Kansas, Arthur D. Little, Inc., Cambridge, Mass., April 1990.

LeMay, W. J.: Empire Abo Field, Southeast New Mexico, in Stratigraphic Oil and Gas Fields Classification, Exploration Methods, and Case Histories. Ed., R. E. AAPG Memoir 16, 1972, p. 472.

Leonard, J: Increased Rate of EOR Brightens Outlook, Oil \& Gas Journal: Production / Enhanced Recovery Report, April 14, 1986, pp. 71-101.

Leonard, J: Steam Dominates Enhanced Oil Recovery, Oil \& Gas Journal: Annual Production Report, v. 80, April 5, 1986, pp. 139-159.

Lloyd, E. R.: Correlation Chart, Permian of West Texas and New Mexico, West Texas Geological Society , 1952, in Jones, T. S., 1953.

Loucks, R. G. and J. H. Anderson: Depositional Facies, Diagenetic Terrains, and Porosity Development in Lower Ordovician Ellenberger Dolomite, Puckett Field, West Texas, in Carbonate Petroleum Reservoirs. Eds. P. O. Roehl and P. W. Choquette, Springer-Verlag, NY, NY, 1985, pp. 19-38.

Malek-Aslani, M: Permian Patch-Reef Reservoirs, North Anderson Ranch Field, Southeastern New Mexico, in Carbonate Petroleum Reservoirs. Eds., P. O. Roehl and P. W. Choquette, Springer-Verlag, NY, NY, 1985, pp. 265-276.

Maples, J. W.: Crude Oil Prices 1991, Kern County Assessor, Oil and Gas Properties Division, Kern County, California, February 1991.

Maples, J. W.: Oil and Gas Properties Appraisal Parameters, 1990-1991, Kern County Assessor, Kern County, California, March 1990.

Mazzullo, S. J.: Stratigraphy and Depositional Mosaics of Lower Clear Fork and Wichita Groups (Permian), Northern Midland Basin, Texas, AAPG Bulletin No. 66, February 1982, pp. 210-227.

Mazzullo, S. J.: Pennsylvanian Facies-Diagenetic Reservoirs, Lower Strawn Formation, Seminole Southeast Field, Midland Basin, West Texas, in Carbonate Petroleum Reservoirs. Eds., P. O. Roehl and P. W. Choquette, Springer-Verlag, NY, NY, 1985, pp. 227-238.

Mickey, V.: Thermal Project to Heat Heavy Paluxy Oil, Drill Bit, 1984, pp. 26-27.

Moritis, G.: $\mathrm{CO}_{2}$ and $\mathrm{HC}$ Injection Lead EOR Production Increase, Oil \& Gas J., Biennial EOR Survey, April 23, 1990. 
Nelson, E., $€$ d.: The Stratigraphic Distribution of Hydrocarbon Production From 12 Counties in the Abilene Area, Abilene Geological Society, Abilene, TX, 1978, p. 183.

Olsen, D. K., W. I. Johnson and E. B. Ramzel: Feasibility Study of Heavy Oil Recovery in the Lower 48 States, Department of Energy Report No. NIPER-521, January 1991.

Olsen, D. K., A. Strycker, E. B. Ramzel: U.S. Heavy Oil Resource, Average Reservoir Data, Department of Energy Report No. NIPER-report in progress, September 1992.

Oriel, S. S., D. A. Myers and E. J. Crosby: West Texas Permian Basin Region, in Paleotectonic Investigations of the Permian System in the United States, U.S. Geologic Survey Professional Paper 515, 1967, pp. 21-60.

Phillips, F. L. and S. R. Whitt: Success of Openhole Completions in the Northeast Butterly Field, Southern Oklahoma, SPE paper 11555 presented at the SPE Production Operation Symposium, Oklahoma City, Oklahoma, February 27-March 1, 1983.

Presley, M. W. and K. A. McGillis: Coastal Evaporite and Tidal-flat Sediments of the Upper Clear Fork and Glorieta Formations, Texas Panhandle, Texas Bureau of Economic Geology, UT Austin, Texas, Report of Investigations No. 115, 1982.

Ramondetta, P. J.: Facies and Stratigraphy of the San Andres Formation, Northern and Northwestern Shelves of the Midland Basin, Texas and New Mexico, Texas Bureau of Economic Geology, UT Austin, Texas, Report of Investigations No. 128, 1982.

Ramondetta, P. J.: Genesis and Emplacement of Oil in the San Andres Formation, Northern Shelf of the Midland Basin, Texas, Texas Bureau of Economic Geology, UT Austin, Texas, Report of Investigations No. 116, 1982.

Sarathi, P. S. and D. K. Olsen: Practical Aspects of Steam Injection Processes. A Handbook for Independent Operators, U.S. Department of Energy Report No. NIPER-580, August 1992.

Thrash, L. S.: Annual Refining Survey, Oil \& Gas J., v. 89, No. 11, March 18, 1991, p. 84.

Thrash, L. S.: Annual Refining Survey, Oil \& Gas J., v. 88, No. 13, March 26, 1990, p. 77.

Todd, R. G.: Oolite-Bar Progradation, AAPG Bulletin No. 60, June 1976, pp. 907-925.

Tyler, N. and N. J. Banta: Oil and Gas Resources Remaining in the Permian Basin: Targets for Additional Hydrocarbon Recovery, Texas Bureau of Economic Geology, UT Austin, Texas, Geologic Circular 89-4, 1989.

Tyler, N., W. E. Galloway, C. M. Garret, Jr. and T. E. Ewing: Oil Accumulation, Production Characteristics, and Targets for Additional Recovery in Major Oil Reservoirs of Texas, Texas Bureau of Economic Geology, UT Austin, Texas, Geologic Circular 84-2, 1984, p. 31.

Tyler, N. and J. C. Gholston: Heterogeneous Deep-Sea Fan Reservoirs, Shackelford and Preston Waterflood Units, Spraberry Trend, West Texas, Texas Bureau of Economic Geology, UT Austin, Texas, Report of Investigations No. 171, 1988.

Van Siclen, D. C.: Depositional Topography-Examples and Theory, AAPG Bulletin No. 42, August 1958, pp. 1897-1913. 
Ward, R. F., C. G.St.C. Kendall and P. M. Harris: Upper Permian (Guadalupian) Facies and Their Association with Hydrocarbons-Permian Basin, West Texas and New Mexico, AAPG Bulletin No. 70, March 1986, pp. 239-262.

Webster, R. E.: Structural Analysis of Devils River Uplift-Southern Val Verde Basin, Southwest Texas, AAPG Bulletin No. 64, February 1980, pp. 221-241.

Williams, B.: Southern California Crude Pipeline Proposed, Oil \& Gas J., November 12, 1990, pp. 34-37.

Wright, W. F.: Petroleum Geology of the Permian Basin, West Texas Geological Society, 1979, p. 98. 


\begin{abstract}
APPENDIX A
Tables 1 and 2 of this appendix lists average reservoir properties obtained from analysis of the public literature. Table 2 contains data on reservoirs where the original-oil-in-place is larger than 1 million barrels. Due to the size of resource, only those reservoirs with $>1$ million barrels OOIP justified research of records to complete the reservoir database, thus Table 1 is a sparse database. Within the constraints of the study, many of the OOIP values are estimated. Table 1 lists reservoir data on all heavy oil reservoirs found in the analysis of secondary data. Estimated values are followed by an asterisk.
\end{abstract}




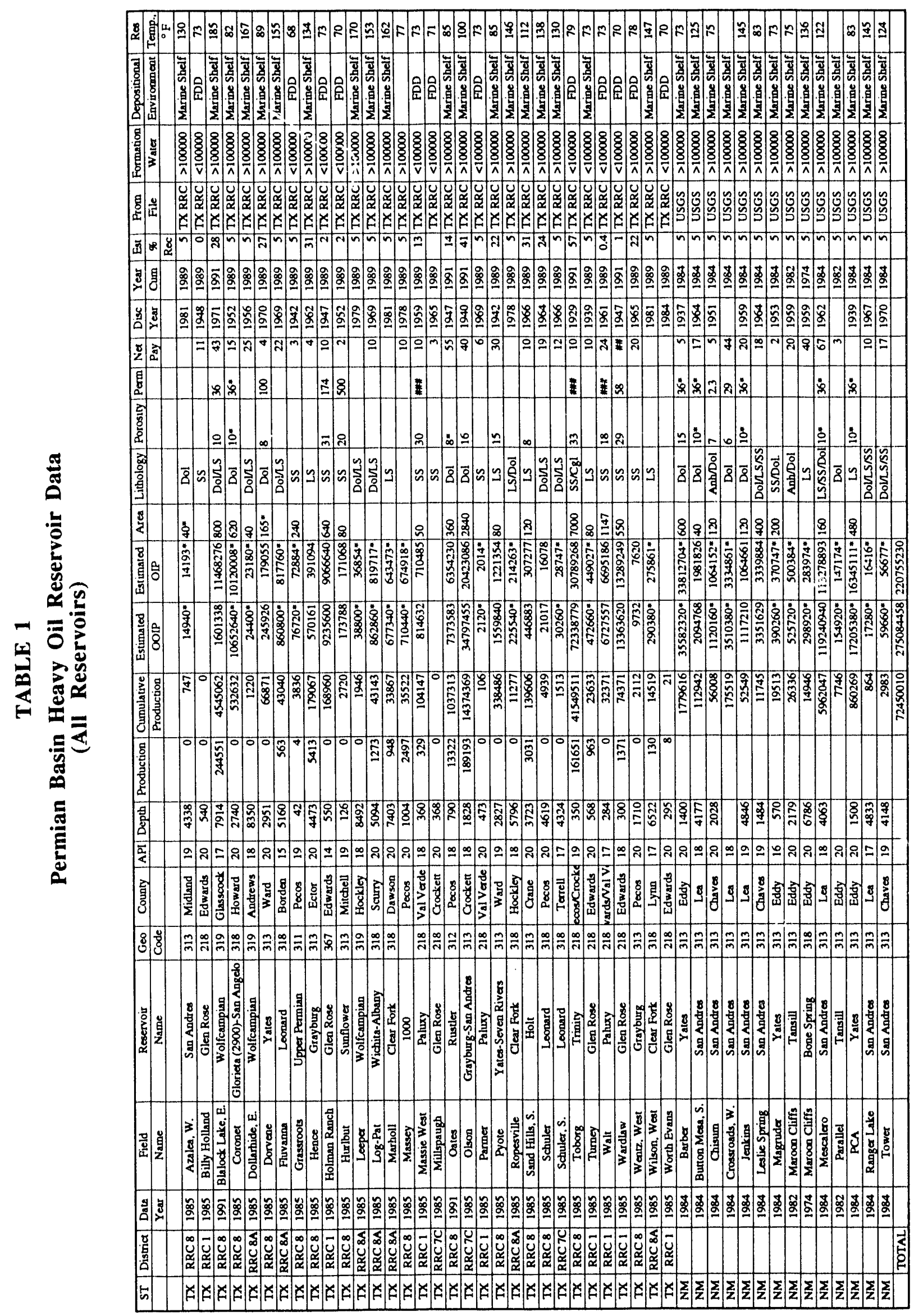



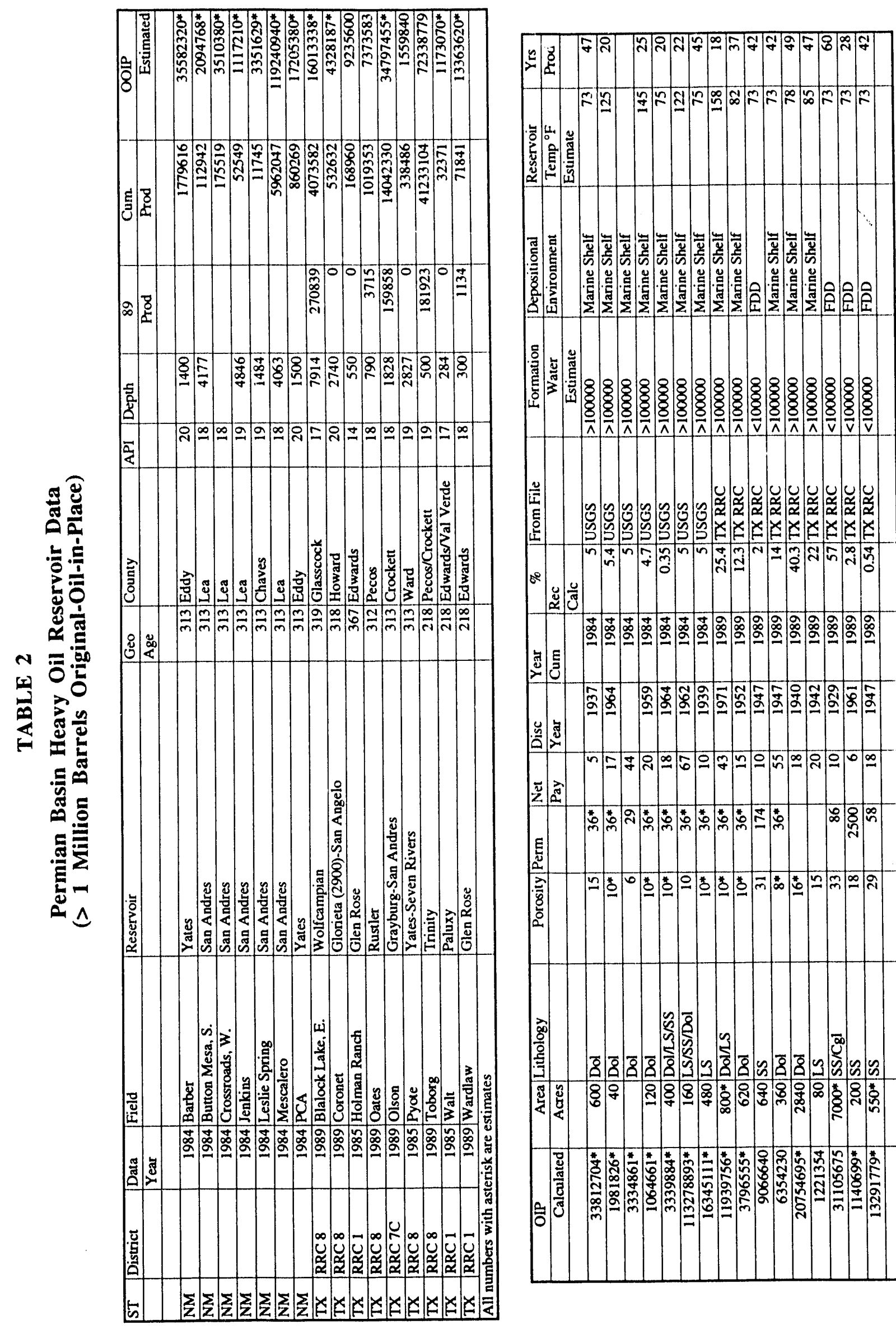

$* \approx$

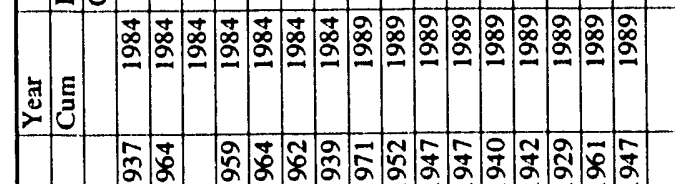

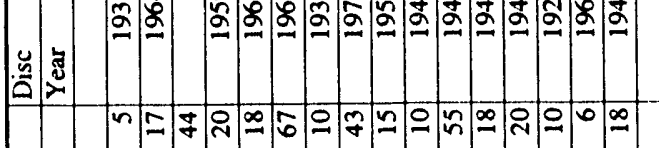

草

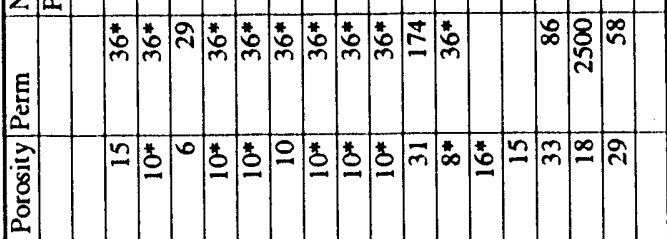

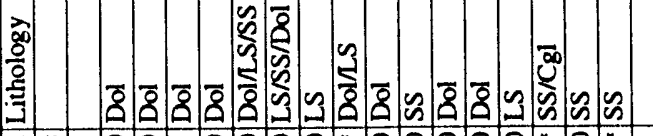
気尊

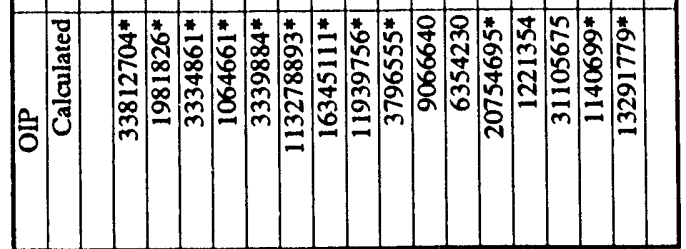



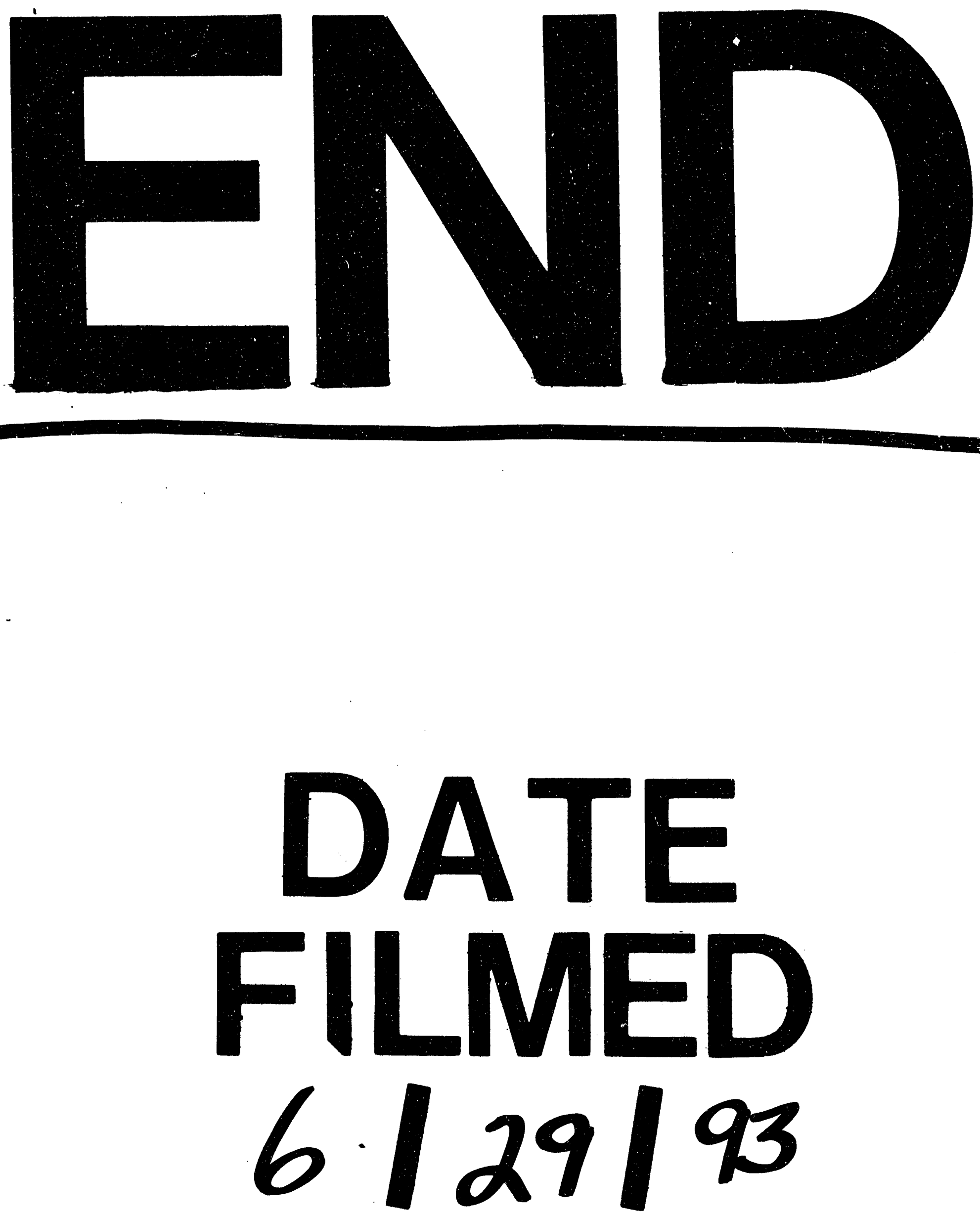
